\title{
Onchocerca-Simulium complexes in Venezuela: can human onchocerciasis spread outside its present endemic areas?
}

\author{
M. G. BASÁÑEZ ${ }^{1,2 *}$, L. YARZÁBAL ${ }^{3}$, H. L. FRONTADO ${ }^{2}$ and N. J. VILLAMIZAR ${ }^{2}$ \\ ${ }^{1}$ Wellcome Trust Centre for Epidemiology of Infectious Disease (WTCEID), University of Oxford, South Parks Road, \\ Oxford OX1 $3 F Y, U K$ \\ ${ }^{2}$ Centro Amazónico para Investigación y Control de Enfermedades Tropicales 'Simón Bolívar' (CAICET). Apartado \\ Postal 59, Puerto Ayacucho 7101, Estado Amazonas, Venezuela \\ ${ }^{3}$ Instituto Internacional de la UNESCO para Educación Superior en América Latina y el Caribe, Apartado Postal \\ 68.394, Caracas 1062-A, Venezuela
}

(Received 3 Fuly 1999; revised 27 August 1999; accepted 27 August 1999)

\section{S U M M A R Y}

The compatibility between sympatric and allopatric combinations of Onchocerca volvulus-anthropophilic species of Simulium was studied in the north-eastern focus of human onchocerciasis as well as in a densely populated locality of the Amazonas State in Venezuela. The objectives were to test the conjecture that local adaptation exists between the parasite and its vectors (the Onchocerca-Simulium complex hypothesis), and assess the possibility of the infection spreading from its present distributional range. For the homologous combination, O. volvulus-S. metallicum cytospecies E in Anzoátegui State (north-eastern focus), parasite yield was $45 \%$ in contrast to $1 \%$ for the heterologous, southern parasite-S. metallicum infection. This was significantly lower than the parasite yield (4-10\%) expected after allowing for the effect of densitydependent limitation of infective larval output described in this paper for S. metallicum. The population of S. exiguum s.l. from southern Venezuela allowed no larval development beyond the L1 stage of either northern or southern parasites. Mechanisms for such refractoriness probably operate at the level of the thoracic muscles, not affecting microfilarial uptake or migration out of the bloodmeal. The parasite yield of southern O. volvulus in S. oyapockense s.l. flies biting man at Puerto Ayacucho (Amazonas) was about $1 \%$, in agreement with the figures recorded for highly compatible sympatric combinations such as $O$. volvulus $-S$. ochraceum s.l. in Guatemala. No infective larval development of the northern parasite was observed in southern $S$. oyapockense. These results, together with considerations of typical worm burdens in the human host, presence/absence of armed cibaria in the simuliids, parasite-induced vector mortality, and fly biting rates, suggest a lower potential for onchocerciasis to spread between the northern and southern endemic areas of Venezuela than that between Amazonian hyperendemic locations and settlements outside this focus with high densities of $S$. oyapockense s.l.

Key words: onchocerciasis spread, cross-infection experiments, local adaptation, Simulium metallicum s.l., S. exiguum s.l., S. oyapockense s.l., Venezuela.

\section{INTRODUCTION}

Two main areas endemic for human onchocerciasis exist in Venezuela, the former situated in the northcentral (Arends, Rondón \& González, 1954) and north-eastern (Potenza, Febres-Cordero \& Anduze, 1948) mountain ranges of the country (the Altamira and Caripe foci, respectively), and the latter in the southern Amazonian region (the Sierra Parima highlands and Upper Orinoco lowlands), close to the border with Brazil (Rassi et al. 1977; Basáñez \& Yarzábal, 1989). In the northern area the infection is transmitted mainly by Simulium metallicum Bellardi s.l. (Peñalver, 1961; Lewis \& Ibáñez de Aldecoa, 1962; Grillet et al. 1994), whereas in the Amazonian focus, S. guianense Wise s.l. (often referred to as $S$. pintoi), S. oyapockense Floch and Abonnenc s.l./S.

* Corresponding author: WTCEID, University of Oxford, South Parks Road, Oxford OX1 3FY, UK. Tel: +44 0(1865) 281221. Fax : + 44 0(1865) 281048. E-mail: mariagloria.basanez@wellcome-epidemiology.oxford.ac.uk roraimense Nunez de Mello (also referred to as $S$. amazonicum and S. cuasisanguineum), and possibly $S$. incrustatum Lutz/S. limbatum Knab (as $S$. yarzabali) are the vectors (Rassi et al. 1977; Takaoka et al. 1984 a; Basáñez et al. 1988; Shelley et al. 1997). S. exiguum Roubaud s.l. occurs in both foci but, whereas it might play a minor role in the north (Duke, 1970), its man-biting rate within the southern focus seems too low to warrant vectorial status (Vivas-Martínez et al. 1998). However, outside the southern onchocerciasis area, the man-seeking density of S. exiguum s.l. may reach very high levels. Members of this species complex play a major vectorial role in Ecuador (Shelley \& Arzube, 1985; Shelley, Procunier \& Arzube, 1986), being the only species transmitting Onchocerca volvulus Leuckart in Colombia (Tidwell et al. 1980; Corredor et al. 1998). S. oyapockense/roraimense bites man in high numbers along the main river systems of the Amazonas region of Venezuela, acting as a vector of Mansonella ozzardi Manson in the middle reaches of the Orinoco river 
(as S. sanchezi (Yarzábal et al. 1985)) and of $O$. volvulus in the Upper Orinoco region (M. E. Grillet, unpublished observations).

The notion of the existence of well-adapted Onchocerca-Simulium complexes, initially proposed by Duke, Lewis \& Moore (1966) in Cameroon, and later confirmed elsewhere in Africa (Philippon, 1977), was based on the observation that microfilariae (mf) of West African forest parasites developed efficiently in $S$. damnosum from West African forest but poorly or not at all in Sudan-savanna flies. Conversely, the success of Sudan-savanna parasites was high when developing within savanna $S$. damnosum but significantly reduced within forest flies. Later, reciprocal cross-infection studies between West Africa and Guatemala (De León \& Duke, 1966; Duke, Moore \& De León, 1967), and West Africa and northern Venezuela (Duke, 1970), documented that homologous parasite-vector combinations (i.e. from the same geographical region) were more successful than heterologous ones (from allopatric endemic areas).

In an evolutionary context, host-parasite interactions are expected to result in geographical patterns of adaptation in which parasites are better able to infect their local host populations (Ebert, 1994; Lively \& Jokela, 1996). This has been confirmed by recent experimental infection studies across a wide variety of host-parasite systems (Parker, 1985; Lively, 1989; Failloux et al. 1995). However, non-significant differences have been found between Guatemalan and North Venezuelan $O$. volvulus populations in their ability to infect local blackfly vectors (S. ochraceum, $S$. metallicum, $S$. callidum and $S$. haematopotum in Guatemala, and $S$. metallicum in Venezuela (Takaoka et al. 1986a)), confirming earlier observations (Duke, 1970). This was interpreted as close genetic proximity between these two parasite populations (Takaoka et al. $1986 b$ ).

More recent work, based on analysis of a tandemly repeated DNA sequence family present in the genome of $O$. volvulus $(\mathrm{O}-150)$ has confirmed that West African rainforest and savanna parasite populations are indeed significantly different and that some barrier preventing genetic exchange between these two populations must have developed, the existence of vector-parasite transmission complexes being one of several possible explanations (Zimmerman et al. 1994). However, profound changes in the epidemiological and ecological landscape of West Africa in the last 20 years, partially due to the Onchocerciasis Control Program (OCP), have apparently disrupted such complexes, with important consequences regarding possible recrudescence following cessation of vector control (Toé et al. 1997).

If highly compatible Onchocerca-Simulium complexes exist within each undisturbed main endemic area, the question arises as to the potential for onchocerciasis to spread towards new regions where infected carriers settle and high densities of anthropophilic simuliids occur. This question seems particularly relevant in Neotropical settings, where, coupled with wide distribution of potential vectors, there is increasing population mobility to and from established foci due to mounting economic and social pressures to develop inland areas (Anon, 1986). Evidence is now emerging from Brazil and Ecuador of locally acquired onchocercal infections, or potential for this to take place, outside original endemic areas (Gerais \& Ribeiro, 1986; Guderian \& Shelley, 1992; Charalambous, Shelley \& Arzube, 1997). Laurence \& Pester (1967) described the relatively rapid adaptation of the filarial worm, Brugia patei, to a new mosquito host, Aedes togoi, in the laboratory and discussed the implications of this finding in explaining present distribution of filariases.

In this paper we explore the ability of $O$. volvulus to develop in sympatric and allopatric man-biting blackfly species of northern and southern Venezuela in order to, first, test the conjecture that Onchocerca-Simulium complexes may exist within Venezuelan endemic areas, and second, investigate the vector competence of highly anthropophilic simuliid species occurring close to population centres which, for the reasons mentioned above, may receive an influx of infected carriers, particularly from the highly endemic southern focus. Finally, we review the available data on vector competence of northern Venezuelan populations of $S$. metallicum s.l. and argue that the variable rates of larval success thus far reported are more the result of the operation of density-dependent regulatory processes (Basáñez et al. 1995), than the effect of the temperature conditions under which experimentally infected flies have been maintained (Takaoka et al. 1984b).

\section{MATERIALS AND METHODS}

Study area and carriers of $\mathrm{O}$. volvulus

The work was conducted during August of 1985 in the village of Carrasposo $\left(10^{\circ} 10^{\prime} 06^{\prime \prime} \mathrm{N}, 64^{\circ} 30^{\prime} 30^{\prime \prime}\right.$ W), Anzoátegui State (north-oriental focus), and during September of 1985 in Culebra and AltoCarinagua, located near Puerto Ayacucho, capital of the Amazonas State $\left(5^{\circ} 35^{\prime} 00^{\prime \prime} \mathrm{N}, 67^{\circ} 41^{\prime} 49^{\prime \prime} \mathrm{W}\right)$, approximately $500 \mathrm{~km}$ from the southern focus (Fig. 1). Two carriers of $O$. volvulus participated in the study. The former was from Caratal, $500 \mathrm{~m}$ from Carrasposo (Subject I, a 40-year-old male plantation worker). He had never been elsewhere and was, therefore, considered to be the carrier of the northern parasite population. The latter (Subject II, a 26year-old Ye'kuana school teacher) had resided for 5-7 years in the Yanomami village of Coyowë-theri $\left(2^{\circ} 25^{\prime} 03^{\prime \prime} \mathrm{N}, 64^{\circ} 17^{\prime} 57^{\prime \prime} \mathrm{W}\right)$, a highly endemic community of the Amazonian focus where he 


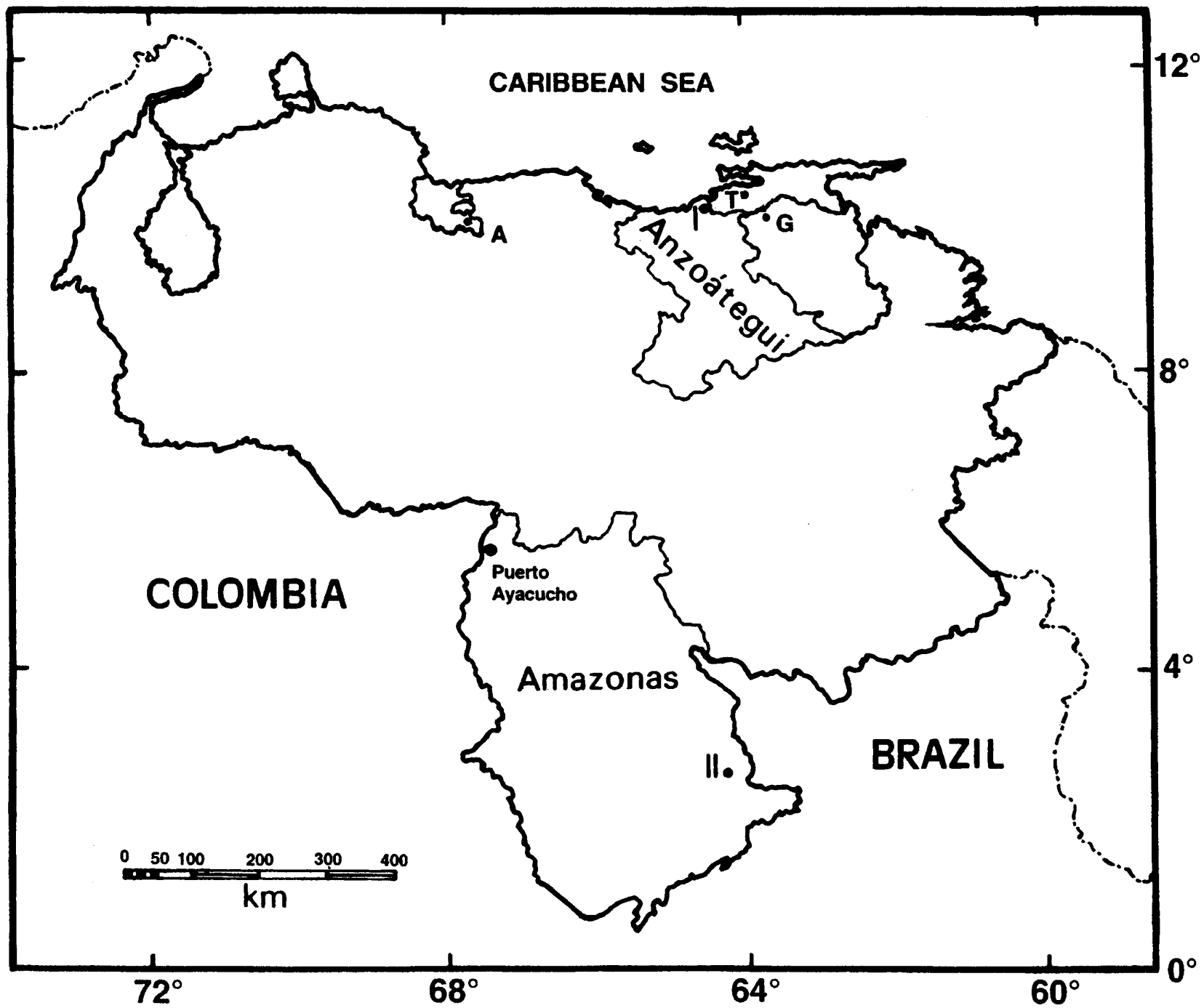

Fig. 1. Map of Venezuela showing the localities where onchocerciasis was acquired by the study participants: I, Carrasposo in Anzoátegui State (north-eastern focus, corresponding to subject I), and II, Coyowë-theri in Amazonas State (southern focus, corresponding to subject II). Fly-feeding experiments in Amazonas took place in Puerto Ayacucho (outside the endemic area). The map also shows the situation of the localities listed in Table 7 for the analysis of vector competence in Venezuelan populations of Simulium metallicum s.l.: A, Altamira (south of Lake Valencia), Carabobo State, north-central focus (Duke, 1970; Grillet et al. 1994; G, Guanaguana (Takaoka et al. 1984b) and Río Chiquito (Takaoka et al. 1986b), Monagas State, and T, Trincheras (Grillet et al. 1994), Sucre State, north-eastern focus.

contracted the infection and became a carrier of the southern parasite population. Table 1 shows their microfilarial loads $(\mathrm{mf} / \mathrm{mg})$ in iliac crest and calf obtained by taking, immediately before the flyfeeding experiments, skin biopsies in each of these body regions ( 2 on the right and 2 on the left hand side) with a Holth sclerocorneal punch followed by incubation of the snips for $24 \mathrm{~h}$ in buffered saline solution (Yarzábal et al. 1983). The mean microfilarial density (MFD, calculated according to Brandling-Bennett et al. 1981) and the prevalence of $\mathrm{mf}$ infection in the population of Caratal/Carrasposo were $1.43 \mathrm{mf} / \mathrm{mg}$ and $31.4 \%(11 / 35)$, determined at the time of the study, and of $45.12 \mathrm{mf} / \mathrm{mg}$ and $84 \cdot 4 \%$ (54/64) in Coyowë-theri (Basáñez \& Yarzábal, 1989). Informed consent was obtained from all study participants and the project was approved by the regional health directorates of both Anzoátegui and Amazonas States.

\section{Entomological procedures}

In the following sections, $S$. metallicum s.l., $S$. exiguum s.l. and $S$. oyapockense s.l. will be alluded to without explicit reference as to their sensu lato status. The member of the $S$. metallicum complex most likely to be involved in onchocerciasis transmission in both Venezuelan north-central and north-eastern foci is cytospecies E (Conn, 1988; Grillet, Barrera \& Conn, 1995). The identity of the cytotypes of $S$. exiguum and $S$. oyapockense occurring in Venezuela is as yet unknown.

At Carrasposo, wild $S$. metallicum flies were individually fed to satiation on the iliac region of 
Table 1. Mean Onchocerca volvulus microfilarial load $(\mathrm{mf} / \mathrm{mg}$ ) in the skin of subject I (carrier of the north-eastern parasite population) and subject II (carrier of the Amazonian parasite) for experimental infection of 3 simuliid species in northern and southern Venezuela

\begin{tabular}{llllll}
\hline \hline & \multicolumn{2}{l}{ Subject I (North-eastern focus) } & & \multicolumn{2}{l}{ Subject II (Amazonian focus) } \\
\cline { 2 - 3 } \cline { 5 - 6 } & $\begin{array}{l}\text { Lower back } \\
\text { (Ia) }\end{array}$ & $\begin{array}{l}\text { Legs } \\
\text { (Ib) }\end{array}$ & & $\begin{array}{l}\text { Lower back } \\
\text { (IIa) }\end{array}$ & $\begin{array}{l}\text { Legs } \\
\text { (IIb) }\end{array}$ \\
\hline Positive snips/total & $2 / 4$ & $3 / 4$ & & $4 / 4$ & $4 / 4$ \\
$\mathrm{GM}^{*}$ & $1 \cdot 41$ & $0 \cdot 94$ & & $111 \cdot 97$ & $10 \cdot 69$ \\
(range) & $(0 \cdot 0-4 \cdot 1)$ & $(0 \cdot 0-1 \cdot 6)$ & & $(88 \cdot 1-155 \cdot 8)$ & $(3 \cdot 3-23 \cdot 1)$ \\
\hline \hline
\end{tabular}

* GM, geometric mean microfilarial skin density including positive and negative snips calculated in the same fashion as for the flies (see text).

Subject I and on the calves of Subject II in an attempt to make microfilarial intakes more comparable and avoid possible high fly mortality resulting from the heavy parasite uptakes expected from the iliac region of Subject II (Omar \& Garms, 1977). Ten females of $S$. exiguum from this locality were also fed on Subject I and dissected from day 0 through day 10 after the feed. (The very low manbiting density of $S$. exiguum during the sampling period at Carrasposo prevented a fuller evaluation of its compatibility with the parasite populations under study.) At Culebra and Alto Carinagua (Puerto Ayacucho), wild flies of $S$. oyapockense and $S$. exiguum were fully engorged on the iliac zone of Subject I and on both legs and lower back of Subject II in an attempt to maximize the probability of infection of $S$. oyapockense. In contrast with $S$. metallicum and $S$. exiguum, $S$. oyapockense possesses a well-developed cibarial armature that destroys an important but variable proportion of ingested microfilariae (Shelley et al. 1987). The fraction of parasites injured by 'armed' simuliids has been shown to be dependent on the density of the intake, decreasing as mf load increases (Basáñez et al. 1995). The total no. of S. metallicum, S. exiguum, and S. oyapockense engorged on each carrier were, respectively, 133, 123 and 182 (Subject I), and 126, 205, and 320 (Subject II), collected over a period of 3-4 days so as to protect the subjects from receiving a higher no. of bites than they would normally be exposed to (average daily biting rates per person were 116 for $S$. metallicum at Carrasposo, 196 for S. exiguum and 204 for $S$. oyapockense at Culebra, and 384 for S. exiguum and 200 for $S$. oyapockense at Alto Carinagua). Flies were collected in individual tubes positioned early on during the feed above lodged insects in order to avoid escape of fully gorged flies.

A group of about 25-35 flies of each species, body region, subject, and locality, was killed between 0 and $12 \mathrm{~h}$ post-engorgement (p.e.) to assess microfilarial intake, damage by the cibarial teeth if present, and migration to the thoracic muscles of the flies. Abdomens were severed and 2 smears on each slide prepared with the bloodmeal and the rest of the abdomen. Once dry, the slides were fixed with methanol in the field and stained with $4 \%$ methylene blue in $3 \%$ acetic acid in the laboratory (Omar \& Garms, 1977). A second group of flies was dissected at $24 \mathrm{~h}$ p.e. to evaluate larval establishment in the thorax (L1 larvae). Finally, a third group of flies was kept in captivity according to methods described elsewhere (Basáñez et al. 1988), fed on sugar solution with antibiotics, and maintained for 6-10 days p.e. to ascertain larval maturation up to the infective stage (L3 larvae) in the surviving flies. In Carrasposo, flies were maintained at a temperature varying between 22 and $32{ }^{\circ} \mathrm{C}$; in Puerto Ayacucho, flies were kept between 25 and $35^{\circ} \mathrm{C}$ in the Simuliidae Laboratory of CAICET. With the exception of the abdomens of the flies dissected at $0-12 \mathrm{~h}$ p.e. the remaining insects or insect sections were all fixed in $80 \%$ ethanol before their staining with Mayer's haemalum and dissection in glycerine (Nelson, 1958). The following morphobiometrical features of L3 larvae were recorded and compared among Onchocerca-Simulium combinations: total length and maximum width; position of and width at the nerve ring; tail length, tail width, and caudal index, the latter defined as the ratio between tail length and tail width measured at the anal pore (Nelson \& Pester, 1962; Porter \& Collins, 1984).

Natural infection was assessed in a sample of 166 $S$. metallicum collected at the same time as the engorged flies in Carrasposo. Since only 1 insect was infected with an early L1 larva, it is henceforth considered that the parasites found in the experimentally infected flies developed from the feed in question. Since Puerto Ayacucho is not endemic for human onchocerciasis, the natural infection of $S$. exiguum and $S$. oyapockense was not investigated.

\section{Data analysis}

The proportions of flies with ingested $\mathrm{mf}$, thoracic larvae, and developing and/or infective larvae among S. metallicum, S. exiguum, and S. oyapockense fed on each subject and body regions, were compared using the chi-square test with Yates' correction in $2 \times c$ 
contingency tables, where $c$ refers to the number of species being compared (Pagano \& Gauvreau, 1993). Fisher exact test (two-tailed) was applied to $2 \times 2$ contigency tables when necessary (Kirkwood, 1988). Because parasite distributions among flies were strongly overdispersed (data not shown), the numbers of larvae per fly among simuliid species were compared using the Kruskal-Wallis test (the nonparametric equivalent of the one-way analysis of variance), correcting the test criterion, $H$, for tied scores (Elliot, 1977). The intensity of infection among flies is reported as the geometric mean (GM) no, of larvae/fly, obtained as follows (Duke, Moore \& De León, 1968),

$\mathrm{GM}=\left[\operatorname{anti} \log \left(\frac{\sum_{i=1}^{i=j} \log \left(x_{i}\right)}{j}\right)\right] \frac{j}{n}$,

where $x_{i}$ is the number of larvae in the $i$ th of $j$ positive flies among a total of $n$ flies examined. Mean infective larval measurements were compared using one-way analysis of variance. When results were significant pairs of means were compared by $t$-tests using the multiple procedure of Bonferroni, in which the significance level that must be applied to each individual comparison depends on the predetermined overall level of significance and the number of tests being conducted (Pagano \& Gauvreau, 1993). Since the ratio of 2 random normal variates is itself not normally distributed, comparisons of caudal indices were carried out using the Kruskal-Wallis test (Siegel, 1956).

Vector competence of $\mathrm{S}$. metallicum cytospecies $\mathrm{E}$ in northern Venezuela

The term vector competence encapsulates those factors affecting pathogen uptake by, development within, and output from the vector host (Spielman $\&$ James, 1990). Analysis of data from this work as well as from Duke (1970), Takaoka et al. (1984b, $1986 \mathrm{a}, b)$, Grillet (1993) and Grillet et al. (1994) focused, therefore, on the following variables: mean microfilarial skin load/mg, mean microfilarial intake/fly, and proportion of flies with ingested $\mathrm{mf}$ (uptake); mean no. of L3/fly and proportion of flies with L3 larvae (development), and parasite yield (output) defined as the proportion of L3/fly developing in relation to mean $\mathrm{mf}$ load (Pichon, Perrault \& Laigret, 1974).

Dermal intensity of infection and microfilarial intake. In all published data sets, with the exception of that presented by Duke (1970), Holth-type sclerocorneal punches were used to obtain skin snips (ss). When dermal loads were reported as mean no. of $\mathrm{mf} / \mathrm{ss}$, the figures were divided by $0 \cdot 67$, the average weight in milligrams of a snip taken with a Holth punch in Neotropical onchocerciasis surveys (Tidwell et al.
1980; Collins et al. 1980), to obtain the mean no. $\mathrm{mf} / \mathrm{mg}$. This differs from the mean weight of $2.8 \mathrm{mg} / \mathrm{snip}$ reported for west African settings (Prost $\&$ Prod'hon, 1978). Linear regression methods with least squares estimation of the parameters were used to explore the relationship between mean $\mathrm{mf}$ intake/ fly, $m$, and mean $\mathrm{mf}$ skin load/mg, $M$, after taking the logarithm of both variables, a variance-stabilizing transformation (Basáñez et al. 1994). The original model is therefore $m=\alpha M^{\beta}$. When the expression $\log (m)=\log \alpha+\beta \log (M)$ was fitted to the data, the intercept, $\log \alpha$, proved to be indistinguishable from zero (corresponding to $\alpha=1$ ); therefore the function $\log (m)=\beta \log (M)$ was used. The null hypothesis, i.e. that there is proportionality between the original variables, corresponds to $\beta=1 ; \beta \neq 1$ indicates non-linearity (operation of positive or negative feed-back processes if $\beta>1$ or $\beta<1$, respectively).

Proportion of flies with ingested $m f$ and mean microfilarial intake. When the frequency distribution of the no. $\mathrm{mf} / \mathrm{fly}$ is overdispersed, the negative binomial provides an adequate model (Basáñez et al. 1994). In consequence, the relationship between $p$, the proportion of flies with $\mathrm{mf}$ in their bloodmeals and $m$, the mean $\mathrm{mf}$ intake, was explored by fitting the expression $p=1-(1+m / k(m))^{-k(m)}$ by maximum likelihood methods, where $k$ is the clumping parameter of the negative binomial and $k(m)$ permits investigating a possible dependency of $k$ on the mean (Basáñez et al. 1995). Likelihood outputs for different assumptions regarding $k(m)$ were compared using the likelihood ratio statistic, $W=2\left[l\left(\hat{k}_{\text {model } 1}\right)-l\left(\hat{k}_{\text {model } 2}\right)\right]$, which, under the null hypothesis $k_{\text {model } 1}=k_{\text {model } 2}$ has, approximately, a chi-squared distribution with degrees of freedom (D.F.) equal to the difference between the number of parameters estimated by each of the models under comparison (Cox \& Oakes, 1984; Clayton \& Hills, 1993).

Proportion of L3 larvae developing from a given $m f$ load. For each of the data points available the parasite yield $(P Y)$ was calculated dividing $L$, the mean no. L3/fly in flies surviving the extrinsic incubation period, by $M$ or $m$, the mean no. $\mathrm{mf} / \mathrm{mg}$ or/fly, and the relationship was explored between $P Y$ and increasing $\mathrm{mf}$ intensity. $P Y=L / M$ was finally selected because Grillet et al. (1994) reported skin density but not $\mathrm{mf}$ intake. The model $P Y=\delta /(1+\gamma M)$ was fitted by non-linear regression methods. Because $\delta$ proved to be statistically indistinguishable from 1 , the simpler function $P Y=$ $1 /(1+\gamma M)$ was used. The null hypothesis of proportionality corresponds to $\gamma=0$, indicating that $P Y$ remains constant (and equal to unity) regardless of $\mathrm{mf}$ density; $\gamma>0$ would describe that $P Y$ decreases with intensity of infection, i.e. that there is 
Table 2. Intake and thoracic establishment of Onchocerca volvulus microfilariae from the Venezuelan north-eastern (I) and Amazonian (II) foci in Simulium metallicum s.l., Simulium exiguum s.l. and Simulium oyapockense s.l.

(The statistical tests comparing the numbers of larvae/fly among fly species are not performed on the geometric means but on the raw counts (see Appendix). The GM values are shown here to summarize the data in a format comparable with published accounts; $\mathbf{a}$, indicates iliac region; $\mathbf{b}$, denotes legs. Fractions and means followed by the same letter are not significantly different.)

\begin{tabular}{|c|c|c|c|c|}
\hline $\begin{array}{l}\text { Blackfly species... } \\
\text { (cibarium) }\end{array}$ & & $\begin{array}{l}\text { S. metallicum s.l. } \\
\text { (unarmed) }\end{array}$ & $\begin{array}{l}\text { S. exiguum s.l. } \\
\text { (unarmed) }\end{array}$ & $\begin{array}{l}\text { S. oyapockense s.l. } \\
\text { (armed) }\end{array}$ \\
\hline Locality... & Subject & $\begin{array}{l}\text { Carrasposo } \\
\text { Anzoátegui State }\end{array}$ & $\begin{array}{l}\text { Culebra and A } \\
\text { Puerto Ayacuc }\end{array}$ & $\begin{array}{l}\text { inagua } \\
\text { hazonas State }\end{array}$ \\
\hline \multicolumn{5}{|l|}{ 0-12 h p.e. } \\
\hline \multicolumn{5}{|l|}{ No. of flies with ingested } \\
\hline \multirow[t]{3}{*}{$\mathrm{mf} /$ total dissected $(\%)$} & Ia & $14 / 24^{c}(58 \cdot 3)$ & $17 / 23^{c}(73 \cdot 9)$ & $5 / 33^{d}(15 \cdot 2)$ \\
\hline & IIa & - & $25 / 25^{c}(100 \cdot 0)$ & $29 / 30^{c}(96 \cdot 7)$ \\
\hline & $\mathrm{IIb}$ & $21 / 25^{c}(84 \cdot 0)$ & $29 / 36^{c}(80 \cdot 6)$ & $17 / 26^{c}(65 \cdot 3)$ \\
\hline \multirow{3}{*}{ GM no. of ingested $\mathrm{mf} / \mathrm{fly}$} & $\mathrm{Ia}$ & $2 \cdot 13^{c}$ & $2 \cdot 43^{c}$ & $0 \cdot 20^{d}$ \\
\hline & IIa & - & $184 \cdot 53^{c}$ & $165 \cdot 48^{c}$ \\
\hline & IIb & $10 \cdot 86^{c}$ & $12 \cdot 90^{c}$ & $7 \cdot 21^{c}$ \\
\hline \multicolumn{5}{|l|}{ No. of flies with thoracic } \\
\hline \multirow[t]{3}{*}{$\mathrm{mf} /$ total dissected $(\%)$} & Ia & $3 / 24^{c}(12 \cdot 5)$ & $3 / 23^{c}(13 \cdot 0)$ & $1 / 33^{c}(3 \cdot 0)$ \\
\hline & IIa & - & $23 / 25^{c}(92 \cdot 0)$ & $14 / 30^{d}(46 \cdot 7)$ \\
\hline & IIb & $15 / 25^{c}(60 \cdot 0)$ & $20 / 36^{c}(55 \cdot 6)$ & $1 / 26^{c}(3 \cdot 9)$ \\
\hline \multirow[t]{3}{*}{ GM no. of thoracic $\mathrm{mf} / \mathrm{fly}$} & Ia & $0 \cdot 24^{c}$ & $0 \cdot 38^{c}$ & $0 \cdot 03^{c}$ \\
\hline & IIa & - & $18 \cdot 14^{c}$ & $2 \cdot 39^{d}$ \\
\hline & IIb & $2 \cdot 02^{c}$ & $2 \cdot 99^{c}$ & $0 \cdot 08^{d}$ \\
\hline \multicolumn{5}{|l|}{24 h p.e. } \\
\hline \multicolumn{5}{|l|}{ No. of flies with early L1/ } \\
\hline total dissected $(\%)$ & Ia & $18 / 24^{c}(75 \cdot 0)$ & $22 / 33^{c}(66 \cdot 7)$ & $0 / 42^{d}(0 \cdot 0)$ \\
\hline & IIa & - & $4 / 4^{c}(100 \cdot 0)$ & $18 / 22^{c}(81 \cdot 8)$ \\
\hline \multirow{4}{*}{ GM no. of early L1/fly } & IIb & $13 / 22^{c}(59 \cdot 1)$ & $28 / 43^{c}(65 \cdot 1)$ & $2 / 46^{d}(4 \cdot 4)$ \\
\hline & Ia & $2 \cdot 88^{c}$ & $1.98^{c}$ & $0 \cdot 00^{d}$ \\
\hline & $\mathrm{IIa}$ & - & $13 \cdot 96^{c}$ & $2 \cdot 70^{c}$ \\
\hline & $\mathrm{IIb}$ & $3 \cdot 29^{c}$ & $2 \cdot 68^{c}$ & $0 \cdot 12^{d}$ \\
\hline \\
\hline & & & & \\
\hline \multirow{3}{*}{$\begin{array}{l}\text { No. of flies with larvae (all } \\
\text { stages)/total dissected }(\%)\end{array}$} & Ia & $47 / 80^{c}(58 \cdot 8)$ & $10 / 16^{c}(62 \cdot 5)$ & $1 / 51^{d}(2 \cdot 0)$ \\
\hline & IIa & - & $8 / 8^{c}(100 \cdot 0)$ & $32 / 64^{d}(50 \cdot 0)$ \\
\hline & $\mathrm{IIb}$ & $47 / 73^{c}(61 \cdot 6)$ & $21 / 34^{c}(61 \cdot 8)$ & $3 / 71^{d}(4 \cdot 2)$ \\
\hline \multirow{3}{*}{ GM no. of larvae/fly } & $\mathrm{Ia}$ & $1 \cdot 82^{c}$ & $2 \cdot 02^{c}$ & $0 \cdot 04^{d}$ \\
\hline & $\mathrm{IIa}$ & - & $4 \cdot 50^{c}$ & $1 \cdot 56^{d}$ \\
\hline & IIb & $2 \cdot 17^{c}$ & $2 \cdot 16^{c}$ & $0 \cdot 06^{d}$ \\
\hline
\end{tabular}

density-dependent limitation of larval establishment/development within S. metallicum. Proportionality or limitation are the 2 alternative patterns described for the relationship between $\mathrm{mf}$ input and L3 output in 'unarmed' vectors (Basáñez et al. 1995). For all the tests performed in this work the level of significance was set to 0.05 and they were carried out using Statistica $^{\mathrm{TM}}$ (StatSoft Inc., Tulsa, $\mathrm{OK})$.

\section{RESULTS}

Intake, establishment and development of O. volvulus from northern and southern Venezuela in sympatric and allopatric species of Simulium

In this work, only the combination S. metallicum-O. volvulus from the North was truly sympatric. Tables
2 and 3 summarize, for $S$. metallicum from Carrasposo (north-eastern Venezuela), and S. exiguum and S. oyapockense from Puerto Ayacucho (Amazonas region), the results of the feeding experiments conducted on Subjects I and II ( $a$ stands for iliac and $b$ for legs). Table 2 shows that, when fed on the same body regions, the 3 simuliid species did not generally differ in their microfilarial intakes (with the exception of S. oyapockense fed on Ia). The values of $\chi^{2}$ (chi-square tests on the proportions of flies infected), $H$ (Kruskal-Wallis criterion for the numbers of parasites/fly), and associated $P$ values and D.F. are listed in Appendix A. Although S. exiguum ingested comparatively more $\mathrm{mf}$ than either $S$. metallicum or S. oyapockense, this difference was not significant for either IIa or IIb. In contrast, when fed on Subject Ia, the fraction of infected $S$. oyapockense flies, and 
Table 3. Development of Onchocerca volvulus microfilariae from the Venezuelan north-eastern (I) and Amazonian (II) foci in Simulium metallicum s.l., Simulium exiguum s.l. and Simulium oyapockense s.l.

(See footnotes to Table 2.)

\begin{tabular}{|c|c|c|c|c|}
\hline $\begin{array}{l}\text { Blackfly species... } \\
\text { (cibarium) }\end{array}$ & & $\begin{array}{l}\text { S. metallicum s.l. } \\
\text { (unarmed) }\end{array}$ & $\begin{array}{l}\text { S. exiguum s.l. } \\
\text { (unarmed) }\end{array}$ & $\begin{array}{l}\text { S. oyapockense s.l. } \\
\text { (armed) }\end{array}$ \\
\hline Locality... & Subject & $\begin{array}{l}\text { Carrasposo } \\
\text { Anzoátegui State }\end{array}$ & $\begin{array}{l}\text { Culebra and Alto Carinagua } \\
\text { Puerto Ayacucho, Amazonas }\end{array}$ & State \\
\hline \multicolumn{5}{|l|}{ 6-10 days p.e. } \\
\hline \multirow{3}{*}{$\begin{array}{l}\text { No. of flies with } \mathrm{L} 1-\mathrm{L} 2 / \\
\text { total dissected }(\%)\end{array}$} & Ia & $33 / 80^{c}(41 \cdot 3)$ & $10 / 16^{c}(62 \cdot 5)$ & $1 \cdot 51^{d}(2 \cdot 0)$ \\
\hline & IIa & - & $8 / 8^{c}(100 \cdot 0)$ & $5 / 64^{d}(7 \cdot 7)$ \\
\hline & $\mathrm{IIb}$ & $45 / 73^{c}(61 \cdot 6)$ & $21 / 34^{c}(61 \cdot 8)$ & $0 / 71^{d}(0 \cdot 0)$ \\
\hline \multirow{3}{*}{$\begin{array}{l}\text { GM no. of L1-L2 } \\
\text { larvae/fly }\end{array}$} & Ia & $0 \cdot 97^{c}$ & $2 \cdot 02^{c}$ & $0 \cdot 04^{d}$ \\
\hline & IIa & - & $4 \cdot 50^{c}$ & $0 \cdot 13^{d}$ \\
\hline & $\mathrm{IIb}$ & $2 \cdot 13^{c}$ & $2 \cdot 16^{c}$ & $0 \cdot 00^{d}$ \\
\hline \multirow{3}{*}{$\begin{array}{l}\text { No. of flies with L3/ } \\
\text { total dissected }(\%)\end{array}$} & Ia & $21 / 80^{c}(26 \cdot 3)$ & $0 / 16^{d}(0 \cdot 0)$ & $0 / 51^{d}(0 \cdot 0)$ \\
\hline & $\mathrm{II} \mathrm{Ia}$ & - & $0 / 8^{c}(0 \cdot 0)$ & $29 / 64^{d}(45 \cdot 3)$ \\
\hline & $\mathrm{IIb}$ & $4 / 73^{c}(5 \cdot 5)$ & $0 / 34^{c}(0 \cdot 0)$ & $3 / 71^{d}(4 \cdot 2)$ \\
\hline \multirow[t]{3}{*}{ GM no. of L3 larvae/fly } & $\mathrm{Ia}$ & $0 \cdot 95^{c}$ & $0 \cdot 0^{d}$ & $0 \cdot 00^{d}$ \\
\hline & $\mathrm{IIa}$ & - & $0 \cdot 0^{c}$ & $1 \cdot 49^{d}$ \\
\hline & $\mathrm{IIb}$ & $0 \cdot 11^{c}$ & $0 \cdot 0^{c}$ & $0 \cdot 06^{c}$ \\
\hline \multirow[t]{3}{*}{ Parasite yield $(\%)$} & $\mathrm{Ia}$ & $44 \cdot 6$ & $0 \cdot 0$ & $0 \cdot 0$ \\
\hline & $\mathrm{IIa}$ & - & $0 \cdot 0$ & $1 \cdot 1$ \\
\hline & $\mathrm{IIb}$ & $1 \cdot 0$ & $0 \cdot 0$ & $0 \cdot 8$ \\
\hline
\end{tabular}

the number of parasites ingested/fly were lower than those of S. metallicum or S. exiguum (see also Fig. 2A). S. metallicum and $S$. exiguum also resembled each other regarding microfilarial migration to the thorax measured at $0-12 \mathrm{~h}$ p.e. (Appendix B) and larval establishment measured both at $24 \mathrm{~h}$ p.e. (early L1 stages: Appendix C) and at 6-10 days p.e. (all larval stages: Appendix D). In contrast, $S$. oyapockense exhibited, in most cases, a significantly lower proportion of flies with thoracic larvae and fewer numbers of larvae/fly than either $S$. metallicum or $S$. exiguum. $S$. oyapockense destroyed a high proportion of the ingested parasites; the fraction damaged appeared to decrease as the mean intake increased (Table $4 ; \chi^{2}=10.59$ and $P=0.001$ with 1 D.F. for the comparison IIa-IIb). The non-significant difference between Ia and II $\left(\chi^{2}=0.99\right.$ and $P=0.32$ for the comparison Ia-IIa; $\chi^{2}=0.19$ and $P=0.67$ for $\mathrm{Ia}-\mathrm{II}$, both with 1 D.F.) is probably due to the small sample size in case of the former. Fig. $2 \mathrm{~B}$ depicts the increasing proportion of undamaged $\mathrm{mf}$ as a function of $\mathrm{mf}$ skin density. This effect is reflected in the numbers of $\mathrm{mf}$ available for migration to and establishment/development in the thorax of the flies, since in $S$. oyapockense both the proportion of flies with larvae and the numbers of larvae per fly were highest for those flies fed on IIa (Table 2).

Regarding larval development (Table 3), there were no significant differences between $S$. metallicum and $S$. exiguum concerning the fraction of flies with and the numbers of developing L1-L2 stages (Appendix E), although in southern $S$. exiguum larval maturation did not proceed beyond the L1 stage. The larvae observed during 6-10 days p.e. in this simuliid population were typically stunted, malformed, and with disintegrating internal structures. Some degree of delayed larval development also took place in $S$. metallicum as attested by the similarity between this species and $S$. exiguum in relation to the fraction of flies with developing larvae and the larval load per fly. In contrast, parasite maturation to the L3 stage was more synchronous in $S$. oyapockense infected with southern $O$. volvulus. Despite this, the proportion of larvae reaching the infective stage per ingested $\mathrm{mf}$ was $45 \%$ for the sympatric combination $S$. metallicum-northern $O$. volvulus in comparison to $1 \%$ for the allopatric counterpart. The parasite yield for $S$. oyapockensesouthern $O$. volvulus was $1 \%$ whereas there was no infective larval output for the heterologous combination.

Table 5 indicates that although there was no difference between the northern and southern parasite populations regarding the proportion of $S$. metallicum flies with cephalic larvae $\left(\mathrm{L} 3_{\mathrm{H}}\right.$ : Fisher exact $P=0.84$ ), the fraction of infective larvae migrating to the head was $75 \%$ in the sympatric compared to $33 \%$ in the allopatric combination ( $\chi^{2}=6.93$ and $P=0.008,1$ D.F.). When $S$. oyapockense from the Puerto Ayacucho (fed on the carrier of Amazonian $O$. volvulus, both body regions com bined), was compared with S. metallicum (fed on both carriers), there was again no difference in the proportion of flies with L3 in the head $\left(\chi^{2}=2.89\right.$ and $P=0 \cdot 24,2$ D.F.). The infective stages of the southern parasite did not differ in their ability to migrate to 

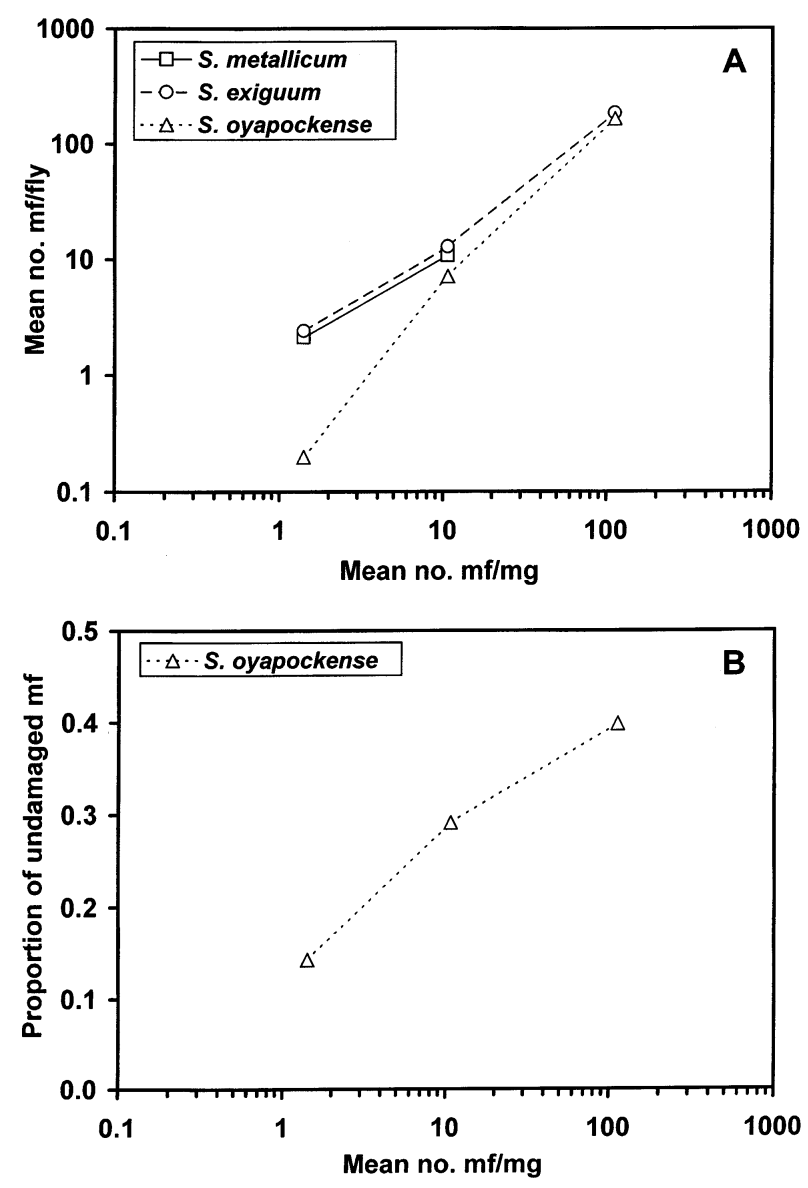

Fig. 2. The relationship, in the Onchocerca volvulus-Simulium combinations investigated in this study (Tables 1, 2 and 4), between mean microfilarial skin load and (A) mean microfilarial intake per fly; (B) proportion of $\mathrm{mf}$ found undamaged in the bloodmeal of the species with cibarial armature (S. oyapockense s.l.).

the cephalic capsule of the flies either in allopatric $S$. metallicum or in Puerto Ayacucho $S$. oyapockense $\left(\chi^{2}=2.04\right.$ and $P=0 \cdot 15,1$ D.F.), but did differ from those of the northern parasite in homologous $S$. metallicum $\left(\chi^{2}=42.73\right.$ and $P \ll 0 \cdot 001,2$ D.F.), indicating that the number of fully infective, cephalic larvae, was higher in the truly sympatric infection.
Table 6 summarizes the morphobiometrical data for the infective larvae harboured by $S$. metallicum and $S$. oyapockense 6-10 days p.e. Although L3 deriving from the heterologous combination southern $O$. volvulus-northern $S$. metallicum were apparently shorter than those developing from the local counterpart, the difference was not significant $(t$-value $=1 \cdot 89$, one-tailed $P=0.03$ and 34 D.F. in the Bonferroni multiple comparisons procedure with individual significance level set at $0 \cdot 017=0 \cdot 05 / 3$ ). However, the L3 obtained from $S$. metallicum were shorter $(t=2 \cdot 39, P=0.01)$, and in the case of the sympatric northern combination, wider $(t=3.82, P<0.001)$ than those harboured by $S$. oyapockense infected with the southern parasite. The distance from the nerve ring to the cephalic end was longer in the southern L3 obtained from this simuliid $(t=4 \cdot 60$, $P \ll 0 \cdot 001$ when compared with those from the homologous northern combination), but in all remaining features the infective stages were similar. All L3 larvae had 3 caudal papillae and a caudal index of about 2, typical of O. volvulus (Duke, 1967; Bain \& Chabaud, 1986).

Of the 10 flies of northern $S$. exiguum fed on Subject I, 4 were found uninfected at the time of dissection (0-8 days p.e.); 4 harboured a geometric mean of 10.5 early L1 larvae/fly (12-72 h p.e.); 1 had $9 \mathrm{~L} 1$ and $1 \mathrm{~L} 2$ on day 9 p.e., and 1 was infective on day 10 p.e. with $1 \mathrm{~L} 3$ thoracic larva.

Vector competence of $\mathrm{S}$. metallicum cytospecies $\mathrm{E}$ in northern Venezuela

Table 7 summarizes available data on vector competence of Venezuelan $S$. metallicum as obtained in homologous experimental infections with $O$. volvulus from the north-central and north-eastern foci. The data are arranged in increasing order of skin $\mathrm{mf}$ density. Neither the mean no. of L3 per infective fly $(2-5)$ nor the proportion of flies with infective larvae $(0 \cdot 03-0 \cdot 4)$ show any systematic variation with temperature of fly maintenance; the consequence, the mean no. of L3 per dissected fly $(L)$ is also rather

Table 4. Proportion of Onchocerca volvulus microfilariae from the Venezuelan north-eastern (I) and Amazonian (II) foci damaged by the cibarial armature of Simulium oyapockense s.l.

(95\% CL are the exact values obtained using the $F$ distribution (Armitage \& Berry, 1994).)

\begin{tabular}{llllll}
\hline \hline & & & & \multicolumn{2}{c}{$95 \% \mathrm{CL}$} \\
\cline { 4 - 6 } Subject & $\begin{array}{l}\text { Mean } \\
\text { mf intake }\end{array}$ & $\begin{array}{l}\text { Total no. of } \\
\text { scored } \mathrm{mf}\end{array}$ & $\begin{array}{l}\text { Fraction of } \\
\text { damaged } \mathrm{mf}\end{array}$ & Lower & Upper \\
\hline Ia & $0 \cdot 2$ & 7 & 0.857 & 0.421 & 0.996 \\
IIb & $7 \cdot 2$ & 237 & 0.709 & 0.651 & 0.767 \\
IIa & $165 \cdot 5$ & 6857 & 0.602 & 0.590 & 0.613 \\
\hline \hline
\end{tabular}


Table 5. Proportion of flies with cephalic L3 larvae among infective flies and proportion of L3 in the head among infective stages in Simulium metallicum s.l. and Simulium oyapockense s.l. 6-10 days after engorgement on Onchocerca volvulus carrier from the Venezuelan north-eastern and Amazonian foci

(Fractions followed by the same letter are not significantly different.)

\begin{tabular}{lll}
\hline \hline Blackfly species & $\begin{array}{l}\text { Subject I } \\
\text { (North-eastern parasite) }\end{array}$ & $\begin{array}{l}\text { Subject II } \\
\text { (Amazonian parasite) }\end{array}$ \\
\hline $\begin{array}{l}\text { S. metallicum s.l. (Carrasposo) } \\
\quad \begin{array}{l}\text { No. of flies with L3 } / \text { total } \\
\text { infective flies }(\%)\end{array}\end{array}$ & $19 / 21^{\mathrm{c}}(90 \cdot 5)$ & $3 / 4^{\mathrm{c}}(75 \cdot 0)$ \\
$\quad \begin{array}{l}\text { No. of L3 Head/total } \\
\text { infective larvae (\%) }\end{array}$ & $69 / 92^{\mathrm{c}}(75 \cdot 0)$ & $4 / 12^{\mathrm{d}}(33 \cdot 3)$ \\
$\begin{array}{l}\text { S. oyapockense s.l. }(\text { Puerto Ayacucho) } \\
\quad \begin{array}{l}\text { No. of flies with L3 } / \text { total } \\
\text { infective flies }(\%)\end{array}\end{array}$ & $0 / 0$ & $24 / 32^{\mathrm{c}}(75 \cdot 0)$ \\
$\quad \begin{array}{l}\text { No. of L3 Head/total } \\
\text { infective larvae }(\%)\end{array}$ & $0 / 0$ & $77 / 130^{\mathrm{d}}(59 \cdot 2)$ \\
\hline \hline
\end{tabular}

Table 6. Mean dimensions \pm S.D. (in $\mu \mathrm{m}$ ) of infective larvae deriving from homologous and heterologous infections of Simulium metallicum s.l. and Simulium oyapockense s.l. 6-10 days after engorgement on Onchocerca volvulus carriers from the Venezuelan north-eastern and Amazonian foci

\begin{tabular}{lcc}
\hline \hline & $\begin{array}{l}\text { Subject I } \\
\text { (North-eastern parasite) }\end{array}$ & $\begin{array}{l}\text { Subject II } \\
\text { (Amazonian parasite) }\end{array}$ \\
\hline S. metallicum s.l. (Carrasposo) & & 3 \\
$n$ & 13 & $453^{\mathrm{c}} \pm 66 \cdot 0$ \\
Total length & $512 \cdot 9^{\mathrm{c}} \pm 56 \cdot 9^{*}$ & $19 \cdot 3^{\mathrm{c}} \pm 1 \cdot 2$ \\
Maximum width & $20^{\mathrm{c}} \pm 1 \cdot 7$ & $58 \cdot 7^{\mathrm{c}} \pm 2 \cdot 8$ \\
Position of nerve ring & $61 \cdot 6^{\mathrm{c}} \pm 4 \cdot 2$ & $18 \cdot 1^{\mathrm{c}} \pm 1 \cdot 2$ \\
Width at nerve ring & $18 \cdot 1^{\mathrm{c}} \pm 1 \cdot 0$ & $32^{\mathrm{c}} \pm 2 \cdot 8$ \\
Tail length & $33 \cdot 9^{\mathrm{c}} \pm 3 \cdot 8$ & $16 \cdot 5^{\mathrm{c}} \pm 0 \cdot 7$ \\
Tail width & $17 \cdot 0^{\mathrm{c}} \pm 0 \cdot 3$ & $1 \cdot 95^{\mathrm{c}}$ \\
Caudal index & $2 \cdot 00^{\mathrm{c}}$ & 21 \\
$S$. oyapockense s.l. (Puerto Ayacucho) & & $554^{\mathrm{d}} \pm 40 \cdot 8$ \\
$n$ & & $19 \cdot 4^{\mathrm{d}} \pm 0 \cdot 5$ \\
Total length & & $69 \cdot 4^{\mathrm{d}} \pm 5 \cdot 3$ \\
Maximum width & & $17 \cdot 3^{\mathrm{c}} \pm 0 \cdot 9$ \\
Position of nerve ring & & $33 \cdot 0^{\mathrm{c}} \pm 2 \cdot 3$ \\
Width at nerve ring & & $16^{\mathrm{c}} \pm 0 \cdot 8$ \\
Tail length & & $1^{\circ} \cdot 98^{\mathrm{c}}$ \\
Tail width & & \\
Caudal index & & \\
\hline \hline
\end{tabular}

* These measurements compare well with those obtained by Grillet (1993) for sympatric O. volvulus-S. metallicum infections in the north-central and north-eastern localities of Altamira $(456 \cdot 2 \pm 86 \cdot 0$ to $494 \cdot 8 \pm 65 \cdot 3 \mu \mathrm{m})$ and Trincheras $(478 \cdot 0 \pm 42 \cdot 9$ to $521 \cdot 7 \pm 60 \cdot 7 \mu \mathrm{m})$ respectively.

constant. Most of the fly-feeding experiments had been performed during the wet season with the exception of AD and TD from Grillet et al. (1994). However, these do not show a consistent difference between the two seasons. Instead, there is an evident declining trend for the parasite yield with intensity of skin infection.

Fig. 3 A depicts the relationship between the log of ingested $\mathrm{mf} / \mathrm{fly}$ and the $\log$ of skin $\mathrm{mf} / \mathrm{mg}$. The regression line goes through the origin with slope $\hat{\beta} \pm$ s.E. $(\hat{\beta})=0 \cdot 958 \pm 0 \cdot 103(r=0 \cdot 87)$. Because the $92 \%$ C.L. for the regression coefficient (0.706-1.211) included 1, the hypothesis of proportionality between the original variables $(\mathrm{mf}$ intake and skin density) was maintained. The relationship between the proportion of flies with ingested $\mathrm{mf}$ and $\mathrm{mf}$ intake was, on the contrary, strongly non-linear (Fig. $3 \mathrm{~B})$, with linear $k$, i.e. $k(m)=k_{0}+k_{1} m\left(k_{0}=0.560\right.$, $\left.k_{1}=0.042, l_{\mathrm{L}}=-125.853\right)$ providing a significantly better fit than constant $k\left(k=0.997, l_{\mathrm{C}}=-128.411\right)$, 
Table 7. Summary of available data on vector competence of populations of Simulium metallicum s.l. (cytospecies E) for Onchocerca volvulus in northern Venezuela

(NC, north-central onchocerciasis focus; NE, north-eastern onchocerciasis focus; W, wet season; D, dry season.)

\begin{tabular}{|c|c|c|c|c|c|c|c|c|c|c|c|c|c|}
\hline \multirow[b]{2}{*}{ Subject } & \multirow{2}{*}{$\begin{array}{l}\text { Mean } \\
\text { no. of } \\
\mathrm{mf} / \mathrm{mg} \\
(M)\end{array}$} & \multirow{2}{*}{$\begin{array}{l}\text { Mean } \\
\text { no. of } \\
\text { mf } /+ \text { ve } \\
\text { fly }\end{array}$} & \multirow{2}{*}{$\begin{array}{l}\text { Flies } \\
\text { with mf/ } \\
\text { total flies } \\
\text { dissected }\end{array}$} & \multirow{2}{*}{$\begin{array}{l}\text { Mean } \\
\text { no. of } \\
\mathrm{mf} / \text { fly } \\
(m)\end{array}$} & \multirow{2}{*}{$\begin{array}{l}\text { Mean } \\
\text { no. of L3/ } \\
\text { + ve fly }\end{array}$} & \multirow{2}{*}{$\begin{array}{l}\text { Flies } \\
\text { with L3/ } \\
\text { total flies } \\
\text { dissected }\end{array}$} & \multirow{2}{*}{$\begin{array}{l}\text { Mean } \\
\text { no. of } \\
\text { L3/ fly } \\
(L)\end{array}$} & \multicolumn{2}{|c|}{ Parasite yield } & \multirow[b]{2}{*}{ Locality } & \multirow{2}{*}{$\begin{array}{l}\text { State } \\
\text { (focus) }\end{array}$} & \multirow{2}{*}{$\begin{array}{l}\text { Month-year } \\
\text { (season) }\end{array}$} & \multirow{2}{*}{$\begin{array}{l}\text { Temperature } \\
\text { of maintenance } \\
\text { (reference) }\end{array}$} \\
\hline & & & & & & & & $L / M$ & $L / m$ & & & & \\
\hline Ia & $1 \cdot 40$ & $3 \cdot 36$ & $13 / 23$ & 1.90 & $3 \cdot 13$ & $23 / 80$ & $0 \cdot 95$ & $0 \cdot 67$ & $0 \cdot 45$ & Carrasposo & $\begin{array}{l}\text { Anzoátegui } \\
\text { (NE) }\end{array}$ & $\begin{array}{l}\text { Aug-1985 } \\
\text { (W) }\end{array}$ & $\begin{array}{l}22-32{ }^{\circ} \mathrm{C} \\
\text { (This work) }\end{array}$ \\
\hline VIII & $1 \cdot 67$ & $3 \cdot 78$ & $53 / 72$ & $2 \cdot 78$ & $1 \cdot 85$ & $44 / 136$ & $0 \cdot 58$ & $0 \cdot 35$ & $0 \cdot 21$ & Altamira & $\begin{array}{l}\text { Carabobo } \\
\text { (NC) }\end{array}$ & $\begin{array}{l}\text { Oct/Nov- } \\
1969 \text { (W) }\end{array}$ & $\begin{array}{l}23-29{ }^{\circ} \mathrm{C} \\
\text { (Duke, 1970) }\end{array}$ \\
\hline- & $2 \cdot 99$ & $4 \cdot 50$ & $8 / 20$ & $1 \cdot 80$ & $2 \cdot 90$ & $14 / 111$ & $0 \cdot 37$ & $0 \cdot 12$ & $0 \cdot 21$ & Guanaguana & $\begin{array}{l}\text { Monagas } \\
(\mathrm{NE})\end{array}$ & $\begin{array}{l}\text { Nov-1982 } \\
\text { (W) }\end{array}$ & $\begin{array}{l}22-28^{\circ} \mathrm{C} \\
\text { (Takaoka et al. } \\
1984 b \text { ) }\end{array}$ \\
\hline IX & $5 \cdot 00$ & $11 \cdot 00$ & $95 / 106$ & $9 \cdot 86$ & $2 \cdot 41$ & $77 / 210$ & $0 \cdot 86$ & $0 \cdot 17$ & $0 \cdot 09$ & Altamira & $\begin{array}{l}\text { Carabobo } \\
\text { (NC) }\end{array}$ & $\begin{array}{l}\text { Oct/Nov- } \\
1969(\mathrm{~W})\end{array}$ & $\begin{array}{l}23-29^{\circ} \mathrm{C} \\
\text { (Duke, } 1970 \text { ) }\end{array}$ \\
\hline $\mathrm{X}$ & $11 \cdot 80$ & $20 \cdot 30$ & $100 / 102$ & $19 \cdot 90$ & $2 \cdot 37$ & $23 / 80$ & $0 \cdot 66$ & $0 \cdot 06$ & $0 \cdot 03$ & Altamira & $\begin{array}{l}\text { Carabobo } \\
\text { (NC) }\end{array}$ & $\begin{array}{l}\text { Oct/Nov- } \\
1969 \text { (W) }\end{array}$ & $\begin{array}{l}23-29^{\circ} \mathrm{C} \\
\text { (Duke, 1970) }\end{array}$ \\
\hline $\mathrm{AD}$ & $13 \cdot 00$ & - & - & - & $3 \cdot 18$ & $17 / 160$ & $0 \cdot 34$ & $0 \cdot 03$ & - & Altamira & $\begin{array}{l}\text { Carababo } \\
\text { (NC) }\end{array}$ & $\begin{array}{l}\text { Mar-1990 } \\
\text { (D) }\end{array}$ & $\begin{array}{l}27^{\circ} \mathrm{C} \\
\text { (Grillet et al. } \\
\quad 1994)\end{array}$ \\
\hline AW & $13 \cdot 00$ & - & - & - & $1 \cdot 77$ & $13 / 138$ & $0 \cdot 17$ & $0 \cdot 01$ & - & Altamira & $\begin{array}{l}\text { Carabobo } \\
\text { (NC) }\end{array}$ & $\begin{array}{l}\text { Sep-1990 } \\
\text { (W) }\end{array}$ & $\begin{array}{l}27^{\circ} \mathrm{C} \\
\text { (Grillet et al. } \\
\quad 1994)\end{array}$ \\
\hline TD & $13 \cdot 50$ & - & - & - & $5 \cdot 00$ & $2 / 78$ & $0 \cdot 13$ & $0 \cdot 01$ & - & Trincheras & $\begin{array}{l}\text { Sucre } \\
\text { (NE) }\end{array}$ & $\begin{array}{l}\text { Feb-1990 } \\
\text { (D) }\end{array}$ & $\begin{array}{l}27^{\circ} \mathrm{C} \\
\text { (Grillet et al. } \\
\quad 1994)\end{array}$ \\
\hline TW & $13 \cdot 50$ & - & - & - & $2 \cdot 93$ & $14 / 155$ & $0 \cdot 26$ & $0 \cdot 02$ & - & Trincheras & $\begin{array}{l}\text { Sucre } \\
\text { (NE) }\end{array}$ & $\begin{array}{l}\text { Aug-1990 } \\
\text { (W) }\end{array}$ & $\begin{array}{l}27^{\circ} \mathrm{C} \\
\text { (Grillet et al. } \\
\quad 1994)\end{array}$ \\
\hline $\begin{array}{l}\text { FA } \\
\text { Rodríguez }\end{array}$ & $19 \cdot 40$ & $9 \cdot 00$ & $13 / 16$ & $7 \cdot 31$ & $3 \cdot 00$ & $7 / 45$ & $0 \cdot 45$ & $0 \cdot 02$ & $0 \cdot 06$ & Río Chiquito & $\begin{array}{l}\text { Monagas } \\
\text { (NE) }\end{array}$ & $\begin{array}{l}\text { Aug-1984 } \\
\text { (W) }\end{array}$ & $\begin{array}{l}20-24{ }^{\circ} \mathrm{C} \\
(\text { Takaoka et al. } \\
1986 b)\end{array}$ \\
\hline $\begin{array}{l}\text { FA } \\
\text { Rodríguez }\end{array}$ & $58 \cdot 21$ & $48 \cdot 00$ & $20 / 20$ & $48 \cdot 00$ & $3 \cdot 00$ & $2 / 7$ & $0 \cdot 86$ & $0 \cdot 01$ & $0 \cdot 02$ & Río Chiquito & $\begin{array}{l}\text { Monagas } \\
(\mathrm{NE})\end{array}$ & $\begin{array}{l}\text { Aug-1984 } \\
\text { (W) }\end{array}$ & $\begin{array}{l}20-24{ }^{\circ} \mathrm{C} \\
\text { (Takaoka et al. } \\
1986 b)\end{array}$ \\
\hline
\end{tabular}



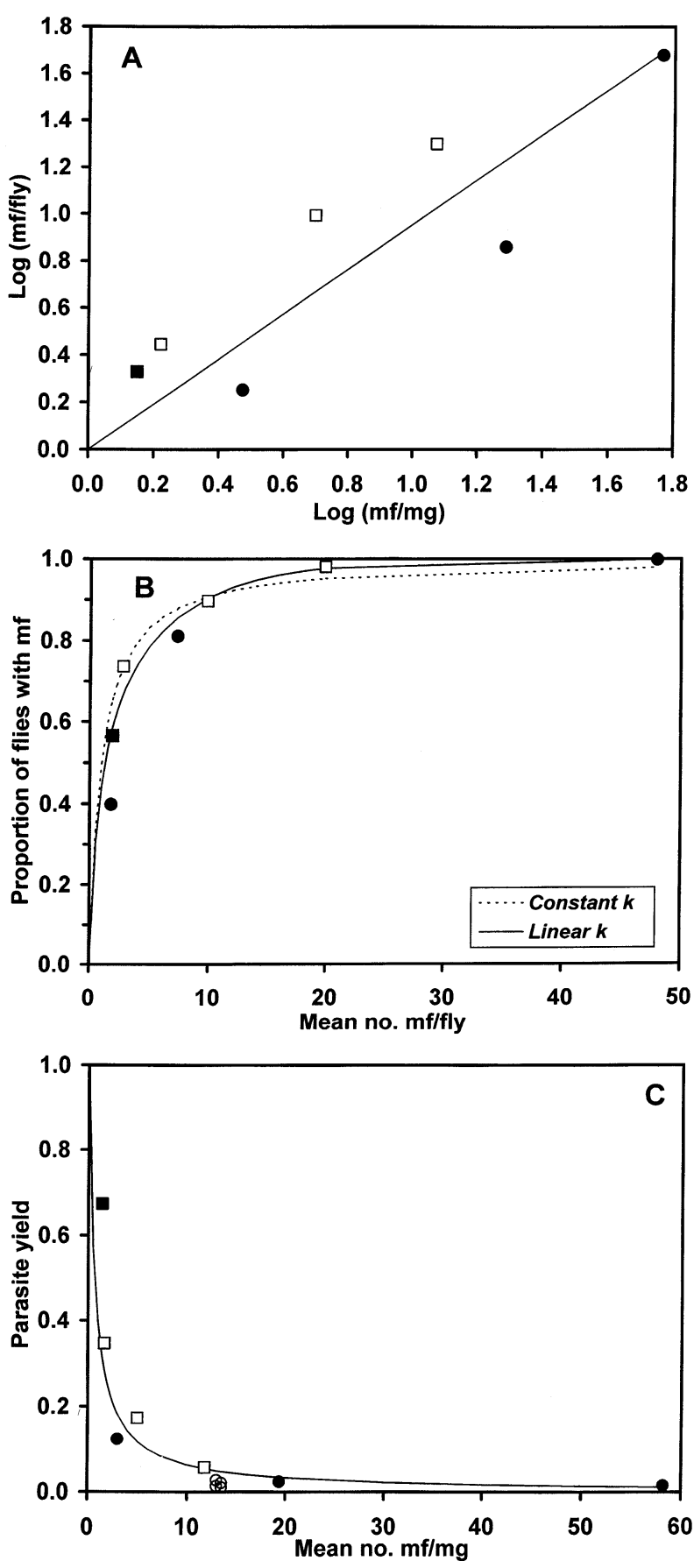

Fig. 3. The relationship, in the sympatric Onchocerca volvulus $-S$. metallicum combinations investigated in Venezuela (Table 7), between mean microfilarial skin load and (A) mean microfilarial intake per fly. The fitted line is the regression function $\log (m)=\beta \log (M)$ where $m=$ mean no. of $\mathrm{mf} / \mathrm{fly}$ and $M=$ mean no. of $\mathrm{mf} / \mathrm{mg}$; (B) proportion, $p$, of flies with ingested $\mathrm{mf}, m$. The lines correspond to the expression $p=1-(1+m / k(m))^{-k(m)}$ with negative binomial parameter $k$ fitted as a constant (----), or as a linear function of the mean (-). (C) Parasite yield, $P Y$, calculated as the proportion of $\mathrm{mf} /$ fly developing to the infective stage. The fitted line is the monotonically decreasing function $P Y=(1+\gamma M)^{-1}$ (see text). Markers are data points from: $(\square)$ this work; $(\square)$ Duke (1970);

(O) Takaoka et al. $(1984 b, 1986 b)$, and ( $\bigcirc)$ Grillet (1993) and Grillet et al. (1994). with $W=5 \cdot 12$, and $P=0 \cdot 024$. Finally, parasite yield was a monotonically decreasing function of skin load (Fig. $3 \mathrm{C}$ ), with $\hat{\gamma} \pm$ s.E. $(\hat{\gamma})$ (parameter estimate of the severity of density-dependence) equal to $1.515 \pm$ $0 \cdot 285(95 \%$ C.L. $=0 \cdot 881-2 \cdot 150)$. This indicates a strong limitation of parasite development to the infective stage in S. metallicum, with the non-linear model explaining $77.3 \%$ of the observed variation $(r=0 \cdot 88)$.

\section{DISCUSSION}

Because we did not attempt to tease apart blackfly susceptibility and onchocercal infectivity, we use the term compatibility (Morand, Manning \& Woolhouse, 1996) to refer to infective larval output in the flies, in terms of both prevalence and intensity of infection. A greater compatibility between local $O$. volvulus-Simulium populations was found in the case of $S$. metallicum when compared with the allopatric combination. Due to the phenomenon of limitation herein described for $S$. metallicum, and with the parameter values estimated, the parasite yield $(L / M)$ for a skin load of $10.7 \mathrm{mf} / \mathrm{mg}$ (corresponding to the legs of the carrier of the southern parasite) would have been expected to vary between 4 and $10 \%$. In contrast, only $1 \%$ of these $\mathrm{mf}$ reached the infective stage. From the data it is clear that this difference cannot be ascribed to defective microfilarial migration or early establishment in the thoracic muscles but rather to mechanisms acting on larval moult and/or development to the L3 stage. Migration to the head of the flies, but not total larval length, was also reduced in the heterologous infection.

$S$. metallicum for the northern focus and $S$. exiguum from Puerto Ayacucho did not differ in their microfilarial uptake or in the ability of the ingested mf to invade their thoracic muscles; neither did they differ in their pre-infective larval loads or in the proportion of flies with L1-L2 on days 6-10 p.e. This supports previous reports of delayed larval development and certain degree of asynchrony in both S. metallicum (Collins, 1979; Tidwell et al. 1980; Grillet et al. 1994) and S. exiguum (Shelley \& Arzube, 1985; Tidwell et al. 1980; Collins et al. 1995). However, in contrast to $S$. metallicum, no larval development proceeded beyond the L1 stage in this middle Orinoco population of $S$. exiguum. Although very few north-eastern $S$. exiguum were infected in this work, 1 of 10 flies fed on Subject I harboured one L3 larva on day 10 p.e. confirming earlier findings on sympatric infections (Duke, 1970). The $S$. exiguum complex has an ample distribution is South America comprising a number of sibling cytospecies and related cytotypes (Shelley, 1988; Charabous, Shelley \& Arzube, 1993), which vary widely in their vector efficiency (Shelley et al. 1997). It is likely that $\mathrm{S}$. exiguum from north-eastern Venezuela belongs to a different cytotype from that 
of the population biting at Puerto Ayacucho, and that these are themselves different from the populations present in Ecuadorian/Colombian foci.

Due to the presence of a cibarial armature, $S$. oyapockense exhibited reduced rates of microfilarial migration and establishment in the thorax of the flies, particularly when microfilarial intakes were low (Ia and IIb). There was no development of the northern parasite to the infective stage in this simuliid. However, southern $O$. volvulus developed synchronously in $S$. oyapockense from Puerto Ayacucho and parasite yields (about $1 \%$ ) were compatible with those observed in sympatric $S$. ochraceum (armed)-O. volvulus from Guatemala (Collins et al. 1977). An increasing proportion of unscathed $\mathrm{mf}$ with heavier intakes is also in agreement with available observations for the Central American species (Basáñez et al. 1995). The body lengths of $O$. volvulus L3 larvae obtained from S. metallicum were shorter than those from $S$. oyapockense. A similar trend has been observed when infective larvae recovered from $S$. metallicum were compared to those from $S$. ochraceum in Guatemala (Collins, 1979; Ito, Tanaka \& Ochoa, 1980).

Microfilarial uptake was found to be roughly proportional to skin density in $S$. metallicum, $S$. exiguum and $S$. oyapockense as already demonstrated for savanna $S$. damnosum, $S$. guianense and $S$. ochraceum (Basáñez et al. 1994). Based on our analyses, we find little evidence in support of microfilarial concentration as it has been defined in other Onchocerca-Simulium studies i.e. higher numbers of ingested $\mathrm{mf}$ than would be expected from skin loads (De León \& Duke, 1966) or saturation i.e. $\mathrm{mf}$ intakes levelling-off with increasing skin load (Duke, 1962). The problems associated with comparing no. $\mathrm{mf} /$ fly with no. $\mathrm{mf} / \mathrm{mg}$ instead of no. $\mathrm{mf}$ per volume of blood in both vector and human hosts have been discussed by Basáñez et al. (1994). Density-dependent regulation, however, does affect parasite survival/development in the combinations explored here; in $S$. metallicum from northern Venezuela (cytospecies E), a decreasing rate of larval success with $\mathrm{mf}$ density indicates the operation of limitation, probably acting through delayed development rather than through mechanisms associated with the peritrophic matrix, which is thin and slow to form in S. metallicum (Lewis \& Garnham, 1959; Omar \& Garms, 1977). Thus, variable outcome of sympatric $O$. volvulus $-S$. metallicum infections may be more the product of processes regulating parasite abundance than of variable maintenance conditions (Takaoka et al. 1984b). Conversely, density-dependent damage of ingested $\mathrm{mf}$ by $S$. oyapockense could result in initial facilitation as occurs in S. ochraceum (Basáñez et al. 1995; Collins et al. 1995). This conjecture is currently being tested with feeding experiments in the Amazonian focus of southern Venezuela.
A value of the negative binomial parameter $k$ which increases with the mean parasite load has been interpreted as an indication of decreasing aggregation suggestive of the operation of density dependent processes (Guyatt et al. 1990). In S. metallicum, mortality induced by heavy $\mathrm{mf}$ intakes, of the type described for unarmed $S$. damnosum and S. guianense (Basáñez et al. 1996), has been demonstrated by following the survival of fly cohorts fed on carriers with varying intensity of infection (De León $\&$ Duke 1966). Among freshly engorged S. metallicum, a better fit to the relationship between proportion of flies with ingested $\mathrm{mf}$ and mean $\mathrm{mf}$ intake was indeed obtained with a linear rather than a constant $k$. A frequently made interpretation of this result is to ascribe it to early action of parasiteinduced vector mortality since this mechanism would produce decreasing overdispersion by truncating the tails of distributions as $\mathrm{mf}$ intake increases. However, it is possible to demonstrate theoretically that a reduction of vector survival due to increasing parasite acquisition can be accompanied by a constant value of the parameter $k$ (Dietz, 1976 and personal communication).

The population of $S$. exiguum investigated in the present work seems to be refractory to the maturation of both northern and southern Venezuelan $O$. volvulus, larval development ceasing at the $\mathrm{L} 1$ stage for either parasite population without any evidence of melanotic encapsulation. A similar phenomenon has been reported when forest members of $S$. damnosum s.l. are intra-thoracically infected with $O$. lienalis or O. gutturosa, or when Liberian (forest) $S$. sanctipauli is injected with savanna $O$. volvulus $\mathrm{mf}$ (Ham \& Garms, 1986, 1987). Only per os infections were conducted here, and the mechanisms involved in the observed resistance of $S$. exiguum do not appear to affect $\mathrm{mf}$ intake or ability to migrate out of the bloodmeal and into the haemocoele of the flies, contrasting with results for other filaria-vector combinations (Beernsten et al. 1995). More likely, they seem to be driven by tissue-associated factors operating in the thoracic muscles (Wattam \& Christensen, 1992; Ham et al. 1994).

The existence of locally adapted OnchocercaSimulium complexes in west Africa and Neotropical regions has been proposed to be indicative of considerable evolutionary divergence between $O$. volvulus endemic in these 2 geographical areas (Duke, 1970, 1981). More recent work has, however, demonstrated that Central and South American parasite populations are closer to West African savanna isolates than they are to each other (Zimmerman et al. 1994). It has also been suggested that hybridization may be taking place between forest and savanna strains in those areas of West Africa where both co-occur (Toé et al. 1997). The northern and southern Venezuelan $O$. volvulus populations are geographically isolated by the central plains 
('Llanos'), and our results indicate strong local adaptation; however, this may not be accompanied by extensive parasite divergence. In fact, local adaptation of parasites to their hosts does not necessarily imply reproductive isolation or significant reduction of gene flow among parasite populations. Strong local selection in the absence of parasite diversification would be expected for any obligatory parasite that is dispersing among markedly differentiated host populations (Dybdahl \& Lively, 1996).

In conclusion, geographical isolation, strong local parasite-vector adaptation, density-dependent limitation and high mortality of S. metallicum when fed on heavy $\mathrm{mf}$ loads typical of Amazonian focus, destruction of ingested $\mathrm{mf}$ by $S$. oyapockense when infected with low numbers of $\mathrm{mf}$ characteristic of the northern foci, and refractoriness of southern $S$. exiguum populations, all make it unlikely that human onchocerciasis would spread readily between the northern and southern foci of Venezuela. However, the Amazonian focus of human onchocerciasis could extend its range outside its present distribution (Upper Orinoco region) as middle Orinoco popula- tions of $S$. oyapockense bite humans in large numbers (we have recorded daily biting rates $>1000$ in other localities), are intrinsically susceptible to parasite development particularly when feeding on high microfilarial densities, and would suffer reduced rates of parasite-induced mortality due to the protection afforded by the cibarial armature.

M. G. B. acknowledges Consejo Nacional de investigaciones Cientificas y Tecnológicas (CONICIT) of Venezuela (grant no. S1-1473) and the Wellcome Trust. L. Y. thanks CONICIT (S1-1128) and the Delegation Générale de la Recherche Scientifique et Technique (DOSRT) of France (grant no. 81-L-0012). We also thank the support of the regional health authorities (Drs Gracinda Viera de Rodriguez and Armando Simoza) and inspectors (Alberto Guerrero, Guiilermo Lopez, Bernabé Santeliz and José Jacinto Cabezas) in Anzoategul, as well as the invaluable help of staff at CAICET (Marianne Middleveen, Xiomara Pérez, Jesús Gómez, Elsa Añez, Graciana González, Víctor Borges, Pedro Luis Noriega and Rafael Varón in Puerto Ayacucho. Tim Anderson, John Williams and Richard Collins made useful comments in relation to the manuscript. This work is dedicated to the memories of our friends and colleagues Ramón Guarema, Amparo Gómez, and Frédéric Delbreuve.

Appendix A. Values of the chi-square $\left(\chi^{2}\right)$ and Kruskal-Wallis $(H)$ tests, associated probabilities $(P)$ and degrees of freedom (D.F.) for comparisons of Onchocerca volvulus microfilarial intake among Simulium metallicum s.l. (north-eastern Venezuela), Simulium exiguum s.l. and Simulium oyapockense s.l. (Amazonas region) in cross-experimental infections. Subject $I$ is the carrier of northern Venezuelan parasites; Subject II harbours infection from the Amazonian focus.

\begin{tabular}{|c|c|c|c|c|}
\hline $\begin{array}{l}\text { Blackfly species } \\
\text { (cibarium)... }\end{array}$ & & $\begin{array}{l}\text { S. metallicum }(m) \\
\text { (unarmed) }\end{array}$ & $\begin{array}{l}\text { S. exiguum }(e) \\
\text { (unarmed) }\end{array}$ & $\begin{array}{l}\text { S. oyapockense (o) } \\
\text { (armed) }\end{array}$ \\
\hline Locality... & Subject & $\begin{array}{l}\text { Carrasposo } \\
\text { Anzoátegui State }\end{array}$ & $\begin{array}{l}\text { Culebra and Alto Carinagua } \\
\text { Puerto Ayacucho, Amazonas }\end{array}$ & State \\
\hline $\begin{array}{l}0-12 \text { h p.e. } \\
\text { Proportion of } \\
\quad \text { flies with } \\
\text { ingested } \mathrm{mf}\end{array}$ & $\begin{array}{l}\text { Ia } \\
\text { IIa } \\
\text { IIb }\end{array}$ & $\chi_{m e}^{2}=0 \cdot 67, P=0 \cdot 41,1$ D.F. & $\begin{array}{l}\chi_{m o}^{2}=9 \cdot 80, P=0 \cdot 002,1 \text { D.F. } \\
\chi_{m e o}^{2}=2 \cdot 93, P=0 \cdot 23,2 \text { D.F. }\end{array}$ & $\begin{array}{l}\chi_{e o}^{2}=17 \cdot 23, P<0 \cdot 001,1 \text { D.F. } \\
\chi_{e o}^{2}=0 \cdot 85, P=0 \cdot 36,1 \text { D.F. }\end{array}$ \\
\hline $\begin{array}{l}\text { No. of } \\
\text { ingested } \\
\text { mf/fly }\end{array}$ & $\begin{array}{l}\text { Ia } \\
\text { IIa } \\
\text { IIb }\end{array}$ & $H_{m e}=0 \cdot 57, P=0 \cdot 45,1$ D.F. & $\begin{array}{l}H_{m o}=14 \cdot 29, P<0 \cdot 001,1 \text { D.F. } \\
H_{m e o}=3 \cdot 25, P=0 \cdot 20,2 \text { D.F. }\end{array}$ & $\begin{array}{l}H_{e o}=22.59, P<0 \cdot 001,1 \text { D.F. } \\
H_{e o}=0 \cdot 16, P=0 \cdot 69,1 \text { D.F. }\end{array}$ \\
\hline
\end{tabular}

a, Iliac region; b, legs; me, compares S. metallicum with S. exiguum; mo, compares S. metallicum with S. oyapockense; eo, compares $S$. exiguum with $S$. oyapockense; meo, compares $S$. metallicum with $S$. exiguum and S. oyapockense. 
Appendix B. Values of the chi-square $\left(\chi^{2}\right)$ and Kruskal-Wallis $(H)$ tests, associated probabilities $(P)$ and degrees of freedom (D.F.) for comparisons of Onchocerca volvulus microfilarial migration to the thorax among Simulium metallicum s.l. (north-eastern Venezuela), Simulium exiguum s.l. and Simulium oyapockense s.l. (Amazonas region) in cross-experimental infections. Subject I is the carrier of northern Venezuelan parasites; Subject II harbours infection from the Amazonian focus. Footnotes as in Appendix A.

\begin{tabular}{|c|c|c|c|c|}
\hline $\begin{array}{l}\text { Blackfly species } \\
\text { (cibarium)... }\end{array}$ & & $\begin{array}{l}\text { S. metallicum }(m) \\
\text { (unarmed) }\end{array}$ & $\begin{array}{l}\text { S. exiguum (e) } \\
\text { (unarmed) }\end{array}$ & $\begin{array}{l}\text { S. oyapockense (o) } \\
\text { (armed) }\end{array}$ \\
\hline Locality... & Subject & $\begin{array}{l}\text { Carrasposo } \\
\text { Anzoátegui State }\end{array}$ & $\begin{array}{l}\text { Culebra and Alto Carinagua } \\
\text { Puerto Ayacucho, Amazonas }\end{array}$ & State \\
\hline $\begin{array}{l}0-12 \text { h p.e. } \\
\text { Proportion of } \\
\text { flies with } \\
\text { thoracic } \mathrm{mf} \\
\text { No. of } \\
\text { thoracic } \\
\mathrm{mf} / \mathrm{fly}\end{array}$ & $\begin{array}{l}\text { Ia } \\
\text { IIa } \\
\text { IIb } \\
\text { Ia } \\
\text { IIa } \\
\text { IIb }\end{array}$ & $\begin{array}{l}\chi_{m e}^{2}=0 \cdot 007, P=0 \cdot 93,1 \text { D.F. } \\
H_{m e}=0 \cdot 18, P=0 \cdot 67,1 \text { D.F. }\end{array}$ & $\begin{array}{l}\chi_{m e}^{2}=2 \cdot 31, P=0 \cdot 32,2 \text { D.F. } \\
\chi_{m o}^{2}=16 \cdot 15, P<0 \cdot 001,1 \text { D.F. } \\
H_{m e o}=2 \cdot 37, P=0 \cdot 31,2 \text { D.F. } \\
H_{m o}=16 \cdot 22, P<0 \cdot 001,1 \text { D.F. }\end{array}$ & $\begin{array}{l}\chi_{e o}^{2}=10 \cdot 75, P=0 \cdot 001,1 \text { D.F. } \\
\chi_{e o}^{2}=15 \cdot 79, P<0 \cdot 001,1 \text { D.F. } \\
H_{\mathrm{eo}}^{2}=23 \cdot 24, P \ll 0 \cdot 001,1 \text { D.F. } \\
H_{e o}=17 \cdot 55, P<0 \cdot 001,1 \text { D.F. }\end{array}$ \\
\hline
\end{tabular}

Appendix C. Values of the chi-square $\left(\chi^{2}\right)$ and Kruskal-Wallis $(H)$ tests, associated probabilities $(P)$ and degrees of freedom (D.F.) for comparisons of Onchocerca volvulus larval establishment (early L1) among Simulium metallicum s.l. (north-eastern Venezuela), Simulium exiguum s.l. and Simulium oyapockense s.l. (Amazonas region) in cross-experimental infections. Subject $\mathrm{I}$ is the carrier of northern Venezuelan parasites; Subject II harbours infection from the Amazonian focus. Footnotes as in Appendix A.

\begin{tabular}{|c|c|c|c|c|}
\hline $\begin{array}{l}\text { Blackfly species } \\
\text { (cibarium)... }\end{array}$ & & $\begin{array}{l}\text { S. metallicum }(m) \\
\text { (unarmed) }\end{array}$ & $\begin{array}{l}\text { S. exiguum }(e) \\
\text { (unarmed) }\end{array}$ & $\begin{array}{l}\text { S. oyapockense (o) } \\
\text { (armed) }\end{array}$ \\
\hline Locality... & Subject & $\begin{array}{l}\text { Carrasposo } \\
\text { Anzoátegui State }\end{array}$ & $\begin{array}{l}\text { Culebra and Alto Carinagua } \\
\text { Puerto Ayacucho, Amazonas }\end{array}$ & State \\
\hline $\begin{array}{l}24 \text { h p.e. } \\
\text { Proportion of } \\
\text { flies with } \\
\text { early L1 } \\
\text { No. of early } \\
\text { L1/fly }\end{array}$ & $\begin{array}{l}\text { Ia } \\
\text { IIa } \\
\text { IIb } \\
\text { Ia } \\
\text { IIa } \\
\text { IIb }\end{array}$ & $\begin{array}{l}\chi_{m e}^{2}=0 \cdot 15, P=0 \cdot 70,1 \text { D.F. } \\
\chi_{m e}^{2}=0 \cdot 04, P=0 \cdot 84,1 \text { D.F. } \\
H_{m e}=1 \cdot 06, P=0 \cdot 30,1 \text { D.F. } \\
H_{m e}=0 \cdot 008, P=0 \cdot 996,1 \text { D.F. }\end{array}$ & $\begin{array}{l}\chi_{m o}^{2}=39 \cdot 61, P \ll 0 \cdot 001,1 \text { D.F. } \\
\chi_{m o}^{2}=22 \cdot 85, P \ll 0 \cdot 001,1 \text { D.F. } \\
H_{m o}=41 \cdot 30, P \ll 0 \cdot 001,1 \text { D.F. } \\
H_{m o}=26 \cdot 33, P \ll 0 \cdot 001,1 \text { D.F. }\end{array}$ & $\begin{array}{l}\chi_{e o}^{2}=36 \cdot 47, P \ll 0 \cdot 001,1 \text { D.F. } \\
\text { Fisher exact test, } P=0 \cdot 98 \\
\chi_{e o}^{2}=34 \cdot 06, P \ll 0 \cdot 001,1 \text { D.F. } \\
H_{e o}=37 \cdot 62, P \ll 0 \cdot 001,1 \text { D.F. } \\
H_{e o}=3 \cdot 74, P=0 \cdot 053,1 \text { D.F. } \\
H_{e o}=35 \cdot 13, P \ll 0 \cdot 001,1 \text { D.F. }\end{array}$ \\
\hline
\end{tabular}

Appendix D. Values of the chi-square $\left(\chi^{2}\right)$ and Kruskal-Wallis $(H)$ tests, associated probabilities $(P)$ and degrees of freedom (D.F.) for comparisons of Onchocerca volvulus microfilarial intake among Simulium metallicum s.l. (north-eastern Venezuela), Simulium exiguum s.l. and Simulium oyapockense s.l. (Amazonas region) in cross-experimental infections. Subject I is the carrier of northern Venezuelan parasites; Subject II harbours infection from the Amazonian focus.

\begin{tabular}{|c|c|c|c|c|}
\hline $\begin{array}{l}\text { Blackfly species } \\
\text { (cibarium)... }\end{array}$ & & $\begin{array}{l}\text { S. metallicum }(m) \\
\text { (unarmed) }\end{array}$ & $\begin{array}{l}\text { S. exiguum }(e) \\
\text { (unarmed) }\end{array}$ & $\begin{array}{l}\text { S. oyapockense (o) } \\
\text { (armed) }\end{array}$ \\
\hline Locality... & Subject & $\begin{array}{l}\text { Carrasposo } \\
\text { Anzoátegui State }\end{array}$ & $\begin{array}{l}\text { Culebra and Alto Carinagua } \\
\text { Puerto Ayacucho, Amazonas }\end{array}$ & State \\
\hline $\begin{array}{l}\text { 6-10 days p.e. } \\
\text { Proportion of } \\
\text { flies with L1, } \\
\text { L2, L3 } \\
\text { No. of } \\
\text { all larval } \\
\text { stages/fly }\end{array}$ & $\begin{array}{l}\text { Ia } \\
\text { IIa } \\
\text { IIb } \\
\text { Ia } \\
\text { IIa } \\
\text { IIb }\end{array}$ & $\begin{array}{l}\chi_{m e}^{2}=0 \cdot 08, P=0 \cdot 78,1 \text { D.F. } \\
\chi_{m e}^{2}=0 \cdot 002, P=0 \cdot 96,1 \text { D.F. } \\
H_{m e}=0 \cdot 07, P=0 \cdot 79,1 \text { D.F. } \\
H_{m e}=0 \cdot 001, P=0 \cdot 98,1 \text { D.F. }\end{array}$ & $\begin{array}{l}\chi_{m o}^{2}=40 \cdot 85, P \ll 0 \cdot 001,1 \text { D.F. } \\
\chi_{m o}^{2}=54 \cdot 85, P \ll 0 \cdot 001,2 \text { D.F. } \\
H_{m o}=40 \cdot 25, P \ll 0 \cdot 001,1 \text { D.F. } \\
H_{m o}=55 \cdot 87, P \ll 0 \cdot 001,1 \text { D.F. }\end{array}$ & $\begin{array}{l}\chi_{e o}^{2}=28 \cdot 27, P \ll 0 \cdot 001,1 \text { D.F. } \\
\chi_{e o}^{2}=5 \cdot 32, P \ll 0 \cdot 02,1 \text { D.F. } \\
\chi_{e o}^{2}=39 \cdot 97, P \ll 0 \cdot 001,1 \text { D.F. } \\
H_{e o}=29 \cdot 90, P \ll 0 \cdot 001,1 \text { D.F. } \\
H_{e o}=9 \cdot 17, P=0 \cdot 002,1 \text { D.F. } \\
H_{e o}=43 \cdot 69, P \ll 0 \cdot 001,1 \text { D.F. }\end{array}$ \\
\hline
\end{tabular}


Appendix E. Values of the chi-square $\left(\chi^{2}\right)$ and Kruskal-Wallis $(H)$ tests, associated probabilities $(P)$ and degrees of freedom (D.F.) for comparisons of Onchocerca volvulus developing larvae (L1 and L2) among Simulium metallicum s.l. (north-eastern Venezuela), Simulium exiguum s.l. and Simulium oyapockense s.l. (Amazonas region) in cross-experimental infections. Subject I is the carrier of northern Venezuelan parasites; Subject II harbours infection from the Amazonian focus. Footnotes as in Appendix A.

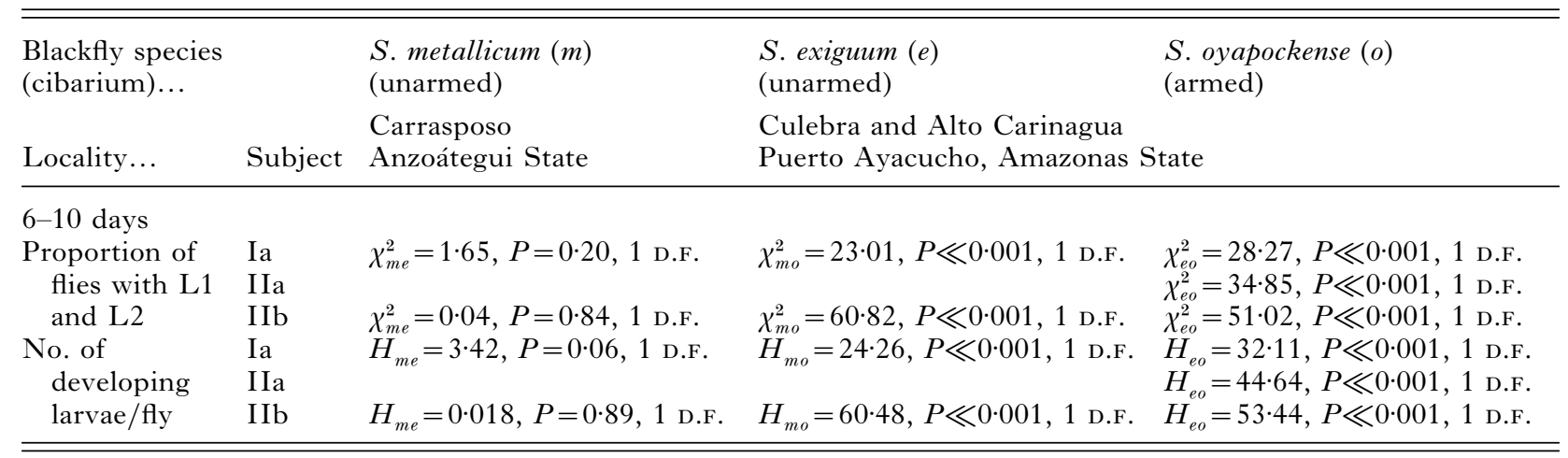

Appendix F. Values of the chi-square $\left(\chi^{2}\right)$ and Kruskal-Wallis $(H)$ tests, associated probabilities $(P)$ and degrees of freedom (D.F.) for comparisons of Onchocerca volvulus infective larvae (L3) among Simulium metallicum s.l. (north-eastern Venezuela), Simulium exiguum s.l. and Simulium oyapockense s.l. (Amazonas region) in cross-experimental infections. Subject I is the carrier of northern Venezuelan parasites; Subject II harbours infection from the Amazonian focus. Footnotes as in Appendix A.

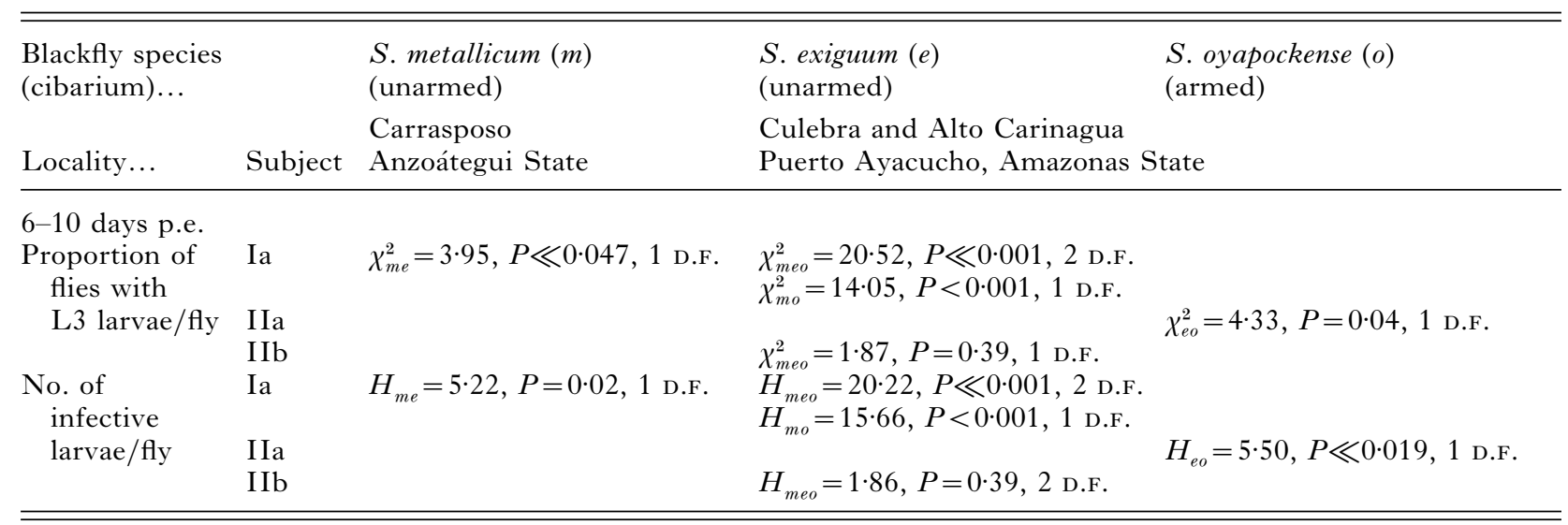

\section{REFERENCES}

ANONYMous. (1986). Is New World onchocerciasis spreading? Parasitology Today 2, 131.

ARENDS, T., RONDÓN, M. F. \& GONZÁlEZ, M. (1954). Nuevo foco de oncocercosis humana en Venezuela. Gaceta Médica de Caracas 62, 645-647.

ARMitage, P. \& BerRy, G. (1994). Statistical Methods in Medical Research, 3rd Edn. Blackwell Scientific Publications, Oxford.

Bain, O. \& Chabaud, A. G. (1986). Atlas des larves infestantes de filaires. Tropical Medicine and Parasitology 37, 301-340.

BasÁÑEZ, M. G., BOUSSINESQ, M., PROD'hON, J., FRONTAdo, H., Villamizar, N. J., Medley, G. F. \& Anderson, R. M. (1994). Density-dependent processes in the transmission of human onchocerciasis: intensity of microfilariae in the skin and their uptake by the simuliid host. Parasitology 108, 115-127.

BASÁÑEZ, M. G., REMME, J. H. F., ALlEy, E. S., BAin, O., SHELley, A. J., MEDLEY, G. F. \& ANDERSON, R. M. (1995). Density-dependent processes in the transmission of human onchocerciasis: relationship between the numbers of microfilariae ingested and successful larval development in the simuliid vector. Parasitology 110, 409-427.

BASÁÑEZ, M. G., TOWNSON, H., Williams, J. R., FRONTADO, H., VILlAMiZAR, N. J. \& ANDERSON, R. M. (1996). Density-dependent processes in the transmission of human onchocerciasis: relationship between microfilarial intake and mortality of the simuliid vector. Parasitology 113, 331-355.

BASÁÑEZ, M. G. \& YARZÁBAL, L. (1989). Onchocerciasis in the Sierra Parima and Upper Orinoco regions, Federal Territory of Amazonas, Venezuela. In Parasitic Diseases: Treatment and Control (ed. Miller, M. J. \& Love, F. J.), pp. 231-256. CRC Press, Florida.

BASÁÑEZ, M. G., YARZÁbal, L., TAKaOKa, H., SUZUKi, H., NODA, S. \& TADA, I. (1988). The vectorial role of several blackfly species (Diptera: Simuliidae) in relation to human onchocerciasis in the Sierra Parima and Upper Orinoco regions of Venezuela. Annals of Tropical Medicine and Parasitology 82, 597-611. 
BEERNTSEN, B. T., SEVERSON, D. W., KLINKHAMMER, J. A., Kassner, V. A. \& Christensen, B. M. (1995). Aedes aegypti: a quantitative trait locus (QTL) influencing filarial worm intensity is linked to QTL for susceptibility to other mosquito-borne pathogens. Experimental Parasitology 81, 355-362.

BRANDLING-BENNETT, A. D., ANDERSON, J., FUGLSANG, H. \& COLlins, R. (1981). Onchocerciasis in Guatemala. Epidemiology in fincas with various intensities of infection. American Fournal of Tropical Medicine and Hygiene 30, 970-981.

Charalambous, M., Shelley, A. J. \& Arzube, M. (1993). Distribution and taxonomic status of chromosomal forms of the onchocerciasis vector Simulium exiguum in central Ecuador. Medical and Veterinary

Entomology 7, 299-303.

CHaralambous, M., Shelley, A. J. \& ARZUBE, M. (1997).

The potential for dispersal of onchocerciasis in Ecuador in relation to the distribution of the vector Simulium exiguum (Diptera: Simuliidae). Memorias do Instituto Oswaldo Cruz 92, 153-156.

Clayton, D. \& Hills, M. (1993). Statistical Models in Epidemiology. Oxford University Press, Oxford. COllins, R. C. (1979). Onchocerciasis transmission potentials of four species of Guatemalan Simuliidae. American Fournal of Tropical Medicine and Hygiene 28, 72-75.

COllins, R. C., CAMPBEll, C. C., Wilton, D. P. \& NEWTON, L. (1977). Quantitative aspects of the infection of Simulium ochraceum by Onchocerca volvulus. Tropenmedizin und Parasitologie 28, 235-243.

COLlins, R. C., BRANDLING-BENNETT, A. D., HOLLMAN, R. B., CAMPBell, C. C. \& DARSie, R. F. (1980).

Parasitological diagnosis of onchocerciasis: Comparison of incubation media and incubation times for skin snips. American Fournal of Tropical Medicine and Hygiene 29, 35-41.

COLlins, R. C., LEHMANN, T., VIEIRA-G, J. C. \& GUDERIAN, R. H. (1995). Vector competence of Simulium exiguum for Onchocerca volvulus: implications for the epidemiology of onchocerciasis. American Fournal of Tropical Medicine and Hygiene 52, 213-218.

CONN, J. (1988). A cytological study of the Simulium metallicum complex (Diptera: Simuliidae) from Central and South America. In Biosystematics of Haematophagous Insects (ed. Service, M. W.), pp. 221-243. Clarendon Press, Oxford.

CORREDOR, A., NICHOlls, R. S., DUQUe, S., MUÑoZ DE HOyos, P., Alvarez, C. A., GUdERIAN, R. H., LÓPEZ, H. H. \& PALMA, G. I. (1998). Current status of onchocerciasis in Colombia. American Fournal of Tropical Medicine and Hygiene 58, 594-598.

Cox, D. R. \& OAKes, D. (1984). Analysis of Survival Data. Chapman and Hall, London.

DE LEÓN, J. R. \& DUKE, B. O. L. (1966). Experimental studies on the transmission of Guatemalan and West African strains of Onchocerca volvulus by Simulium ochraceum, S. metallicum and S. callidum. Transactions of the Royal Society of Tropical Medicine and Hygiene 60, 735-752.

DiETz, K. (1976). The transmission dynamics of some helminthic diseases. Proceedings of the 9 th
International Biometric Conference, pp. 175-188. The Biometric Society, Boston.

DUKE, B. O. L. (1962). Studies on factors influencing the transmission of onchocerciasis. II. The intake of Onchocerca volvulus microfilariae by Simulium damnosum and the survival of the parasites in the fly under laboratory conditions. Annals of Tropical Medicine and Parasitology 56, 255-263.

DUKE, B. O. L. (1967). Infective filaria larvae, other than Onchocerca volvulus, in Simulium damnosum. Annals of Tropical Medicine and Parasitology 61, 200-205.

DUKE, B. O. L. (1970). Onchocerca-Simulium complexes, VI. Experimental studies on the transmission of Venezuelan and West African strains of Onchocerca volvulus by Simulium metallicum and S. exiguum in Venezuela. Annals of Tropical Medicine and Parasitology 64, 421-431.

DUKE, B. O. L. (1981). Geographical aspects of onchocerciasis. Annales de la Société Belge de Médecine Tropicale 61, 179-186.

DUKE, B. O. L., LEWIS, D. J. \& MOORE, P. J. (1966). Onchocerca-Simulium complexes. I. Transmission of forest and Sudan-savanna strains of Onchocerca volvulus from Cameroon by Simulium damnosum from various West African bioclimatic zones. Annals of Tropical Medicine and Parasitology 60, 318-336.

DUKE, B. O. L., MOORE, P. J. \& DE LEÓN, J. R. (1967). Onchocerca-Simulium complexes. V. The intake and subsequent fate of a Guatemalan strain of Onchocerca volvulus in forest and Sudan-savanna forms of West African Simulium damnosum. Annals of Tropical Medicine and Parasitology 61, 332-337.

DYBDAHL, M. F. \& LIVELY, C. M. (1996). The geography of coevolution: comparative population structures for a snail and its trematode parasite. Evolution 50, 2264-2275.

EBERT, D. (1994). Virulence and local adaptation of a horizontally transmitted parasite. Science $\mathbf{2 6 5}$, 1084-1086.

Elliot, J. M. (1977). Some Methods for the Statistical Analysis of Samples of Benthic Invertebrates. 2nd Edn. Freshwater Biological Association, Scientific Publication No. 25. Titus Wilson \& Son Ltd., Cumbria.

FAILlOUX, A. B., RAYMOND, M., UNG, A., GLAZIOU, P., MARTIN, P. M. V. \& PASTEUR, N. (1995). Variation in the vector competence of Aedes polynesiensis for Wuchereria bancrofti. Parasitology 111, 19-29.

GERAIS, B. B. \& RIBEIRO, T. C. (1986). Oncocercose: primeiro caso autóctone da região centro-oeste do Brasil. Revista da Sociedade Brasileira de Medicina Tropical 19, 105-107.

GRILlet, M. E. (1993). Estudio de Simulium metallicum, vector principal de oncocercosis en el norte de Venezuela: ecología, competencia vectorial y citotaxonoma. Ph.D. thesis, Universidad Central de Venezuela, Caracas.

GRILleT, M. E., BOtTO, C., BASÁÑEZ, M. G. \& BARRERA, R. (1994). Vector competence of Simulium metallicum s.l. (Diptera: Simuliidae) in two endemic areas of human onchocerciasis in northern Venezuela. Annals of Tropical Medicine and Parasitology 88, 65-75. 
GRILlET, M. E., BARRERA, R. \& CONN, J. (1995). Simulium metallicum cytospecies $\mathrm{E}$ larval habitat characterization in the Altamira focus of onchocerciasis, northern Venezuela. Medical and Veterinary Entomology 9, 195-201.

GUdERIAN, R. H. \& SHELley, A. J. (1992). Onchocerciasis in Ecuador: the situation in 1989. Memorias do Instituto Oswaldo Cruz 87, 405-415.

GUYATT, H. L., BUNDY, D. A. P., MEDLEY, G. F. \& GRENFELL, B. т. (1990). The relationship between the frequency distribution of Ascaris lumbricoides and the prevalence and intensity of infection in human communities. Parasitology 101, 139-143.

HAM, P. J. \& GARMS, R. (1986). Experimental infections of Simulium damnosum cytospecies with human and bovine Onchocerca species. Tropical Medicine and Parasitology 37, 79.

HAM, P. J. \& GARMS, R. (1987). Failure of Onchocerca gutturosa to develop in Simulium soubrense and Simulium yahense from Liberia. Tropical Medicine and Parasitology 38, 135-136.

ham, P. J., Albuquerque, C., BaXter, A. J., Chalk, R. \& HAGEN, H. E. (1994). Humoral immune responses in blackfly and mosquito vectors of filariae. Transactions of the Royal Society of Tropical Medicine and Hygiene 88, 132-135.

ITO, S., TANAKA, I. \& OCHOA-A, J. O. (1980). Comparative studies on the affinities of two black flies, Simulium metallicum and S. ochraceum for larvae of Onchocerca volvulus in Guatemala. Fapanese Fournal of Sanitary Zoology 31, 261-270.

KIRKWOOD, B. (1988). Essentials of Medical Statistics. Blackwell Scientific Publications, Oxford.

LAURENCE, B. R. \& PESTER, F. R. (1967). Adaptation of a filarial worm, Brugia patei, to a new mosquito host, Aedes togoi. Fournal of Helminthology 41, 365-392.

LEWIS, D. J. \& GARnham, P. C. C. (1959). The Simuliidae (Diptera) of British Honduras. Bulletin of

Entomological Research 50, 703-710.

LEWIS, D. J. \& IBÁÑEZ DE ALDECOA, R. (1962). Simuliidae and their relation to human onchocerciasis in northern Venezuela. Bulletin of the World Health Organization 27, 449-464.

LIVELY, C. M. (1989). Adaptation by a parasitic trematode to local populations of its snail host. Evolution 43, 1663-1671.

Lively, C. M. \& JOKELA, J. (1996). Clinal variation for local adaptation in a host-parasite interaction. Proceedings of the Royal Society of London, B 263, 891-897.

MORAND, S., MANNING, S. D. \& WOOLHOUSE, M. E. J. (1996). Parasite-host coevolution and geographic patterns of parasite infectivity and host susceptibility. Proceedings of the Royal Society of London, B 263, 119-128.

NELSON, G. S. (1958). Staining of filarial larvae of insects before dissection. Bulletin of the World Health Organization 19, 204.

NELSON, G. S. \& PESTER, F. R. N. (1962). The identification of infective filarial larvae in Simuliidae. Bulletin of the World Health Organization 27, 473-481.

OMAR, M. S. \& GARMS, R. (1977). Lethal damage to Simulium metallicum following high intakes of
Onchocerca volvulus microfilariae in Guatemala. Tropenmedizin und Parasitologie 26, 169-182.

Pagano, M. \& Gauvreau, K. (1993). Principles of

Biostatistics. Duxbury Press, California.

PARKER, M. A. (1985). Local population differentiation for compatibility in an annual legume and its host-specific pathogen. Evolution 39, 713-723.

PEÑalver, L. M. (1961). Estudio de un foco de oncocercosis en la región central de Venezuela. Determinación del Simulium metallicum y Simulium exiguum como transmisores de la enfermedad en Venezuela. Revista Venezolana de Sanidad y Asistencia Social 26, 898-912.

PHILIPPON, B. (1977). Étude de la transmission d'Onchocerca volvulus (Leuckart, 1893) (Nematoda, Onchocercidae) par Simulium damnosum Theobald, 1903 (Diptera: Simuliidae) en Afrique tropicale. Travaux et Documents de l' O.R.S.T.O.M. (Paris) No. 63

PiCHON, G., PERRAUlt, G. \& LAIGRET, J. (1974). Rendement parasitaire chez les vecteurs de filarioses. Bulletin of the World Health Organization 51, 517-524.

PORTER, C. H. \& COllins, R. C. (1984). Descriptive statistics for the larval stages of Onchocerca volvulus in host-seeking Simulium ochraceum. American Fournal of Tropical Medicine and Hygiene 33, 252-260.

POTENZA, L., FEBRES-CORDERo, R. \& ANDUZE, P. J. (1948). Oncocercosis humana en Venezuela. Gaceta Médica de Caracas 56, 219-220.

PRost, A. \& PROD'hon, J. (1978). Le diagnostique de l'onchocercose. Revue critique des méthodes en usage. Médecine Tropical 38, 519-532.

RASSi, E., MONZÓN, H., CASTILlo, M., HERNÁNDEZ, I., RAMírez-PÉREZ, J. \& CONVIT, J. (1977). Discovery of a new onchocerciasis focus in Venezuela. Bulletin of the PanAmerican Health Organization 11, 41-64.

SHELley, A. J. (1988). Biosystematics and medical importance of the Simulium amazonicum group and the S. exiguum complex in Latin America. In Biosystematics of Haematophagous Insects (ed. Service, M. W.), pp. 203-220. Clarendon Press, Oxford.

Shelley, A. J. \& ARZUBE, M. (1985). Studies on the biology of Simuliidae (Diptera) at the Santiago focus in Ecuador, with special reference to the vectors and disease transmission. Transactions of the Royal Society of Tropical Medicine and Hygiene 79, 328-338.

SHELley, A. J., LOWRY, C. A., MAIA-HERZOG, M., LUNA DIAS, A. P. A. \& MORAES, M. A. P. (1997). Biosystematic studies on the Simuliidae (Diptera) of the Amazonia onchocerciasis focus. Bulletin of the Natural History Museum, London (Entomology) 66, 1-121.

Shelley, A. J., LUNa Dias, A. P. A., MORAes, M. A. P. \& Procunier, W. s. (1987). The status of Simulium oyapockense and $S$. limbatum as vectors of human onchocerciasis in Brazilian Amazonia. Medical and Veterinary Entomology 1, 219-234.

Shelley, A. J., Procunier, w. s. \& ARZUbe, M. (1986). Direct incrimination of Simulium exiguum Cayapa form as a vector of Onchocerca volvulus in Ecuador. Transactions of the Royal Society of Tropical Medicine and Hygiene 80, 845. 
SIEGEL, S. (1956). Nonparametric Statistics for the Behavioral Sciences. International Student Edition. McGraw-Hill Kogakusha Ltd, Tokyo.

SPielman, A. \& JAMES, A. A. (1990). Transmission of vector-borne disease. In Tropical and Geographical Medicine (ed. Warren, K. S. \& Mahmoud, A. A. F.), pp. 146-159. McGraw-Hill, Inc., New York.

TAKAOKA, H., SUZUKI, H., NODA, S., TADA, I., BASÁÑEZ, M. G. \& YARZÁBAL, L. $(1984 a)$ ). Development of Onchocerca volvulus larvae in Simulium pintoi in the Amazonas region of Venezuela. American Fournal of Tropical Medicine and Hygiene 33, 414-419.

TAKAOKA, H., SUZUKI, H., NODA, S., TADA, I., RODUlFO, S., PACHANO, L. \& CONVIT, J. (1984b). Susceptibility of Simulium metallicum to infection with Onchocerca volvulus in Venezuela. Fapanese Fournal of Tropical Medicine and Hygiene 12, 89-96.

TAKAOKA, H., TADA, I., HASHIGUCHI, Y., BABA, M., KORENAGA, M., OCHOA, J. O. \& CONVIT, J. (1986a). Experimental infections of three Guatemalan blackfly species with North Venezuelan Onchocerca volvulus. Fapanese Fournal of Sanitary Zoology 37, 319-323.

TAKAOKa, H., TADA, I., HASHIGUCHI, Y., BABA, M., KORENAGA, M., OCHOA, J. O., CONVIT, J. \& YARZÁBAL, L. $(1986 b)$. A cross-compatibility study of Guatemalan and North Venezuelan Onchocerca volvulus to Simulium metallicum from two countries. Fapanese Fournal of Parasitology 35, 35-41.

TIDWELl, M. A., TIDWELl, M. A., MUÑ̃Z DE HOYOS, P. \& CORREDOR, A. (1980). Simulium exiguum, the vector of Onchocerca volvulus on the Río Micay, Colombia. American Fournal of Tropical Medicine and Hygiene 29, 377-381.

TOÉ, L., TANG, J., BACK, C., KATHOLI, C. R. \& UNNASCH, T. R. (1997). Vector-parasite transmission complexes for onchocerciasis in West Africa. Lancet 349, 163-166.

Vivas-MartíNeZ, S., BASÁÑEZ, M. G., GRILlet, M. E., Weiss, H., вотTO, C., GARCía, M., villamizar, N. J. \& Chavasse, D. C. (1998). Onchocerciasis in the Amazonian focus of southern Venezuela: altitude and blackfly species composition as predictors of endemicity to select communities for ivermectin control programmes. Transactions of the Royal Society of Tropical Medicine and Hygiene 92, 613-620.

WATtAM, A. R. \& CHRistensEn, B. M. (1992). Induced polypeptides associated with filarial worm refractoriness in Aedes aegypti. Proceedings of the National Academy of Sciences, USA 89, 6502-6505.

YARZÁbAL, L., ARANGo, M., BOtTO, C., JAIMES, J. L., SÁNCHEZ-BEAUjON, R. \& RAGA, L. M. (1983). Nuevas observaciones sobre la endemia oncocercósicade la Sierra de Parima, TFA, Venezuela. In Las Filariasis Humanas en el Territorio Federal Amazonas, Venezuela (ed. Yarzábal, L., Holmes, R., Basáñez, M. G., Petralanda, I., Botto, C., Arango, M. \& Schkolnik, S.), pp. 3-19. PROICET-Amazonas, Publicación Cientfica No. 2, Caracas.

YARZÁBAL, L., BASÁÑEZ, M. G., RAMíREZ-PÉREZ, J., RAMíREZ, A., вотto, C. \& YARZÁbal, A. (1985). Experimental and natural infection of Simulium sanchezi by Mansonella ozzardi in the Middle Orinoco region of Venezuela. Transactions of the Royal Society of Tropical Medicine and Hygiene 79, 29-33.

ZimMERMAN, P. A., KATHOli, C. R., WOOTEN, M. C., LANGUNNASCH, N. \& UNNASCH, T. R. (1994). Recent evolutionary history of American Onchocerca volvulus, based on analysis of a tandemly repeated DNA sequence family. Molecular Biology and Evolution 11, 384-392. 